\title{
Application of dental nanomaterials: potential toxicity to the central nervous system
}

\author{
This article was published in the following Dove Press journal: \\ International Journal of Nanomedicine \\ 14 May 2015 \\ Number of times this article has been viewed
}

\author{
Xiaoli Feng' \\ Aijie Chen' \\ Yanli Zhang' \\ Jianfeng Wang ${ }^{2}$ \\ Longquan Shao' \\ Limin Wei ${ }^{2}$ \\ 'Nanfang Hospital, Southern Medical \\ University, Guangzhou, ${ }^{2} \mathrm{School}$ and \\ Hospital of Stomatology, Wenzhou \\ Medical University, Wenzhou, People's \\ Republic of China
}

\begin{abstract}
Nanomaterials are defined as materials with one or more external dimensions with a size of 1-100 nm. Such materials possess typical nanostructure-dependent properties (eg, chemical, biological, optical, mechanical, and magnetic), which may differ greatly from the properties of their bulk counterparts. In recent years, nanomaterials have been widely used in the production of dental materials, particularly in light polymerization composite resins and bonding systems, coating materials for dental implants, bioceramics, endodontic sealers, and mouthwashes. However, the dental applications of nanomaterials yield not only a significant improvement in clinical treatments but also growing concerns regarding their biosecurity. The brain is well protected by the blood-brain barrier (BBB), which separates the blood from the cerebral parenchyma. However, in recent years, many studies have found that nanoparticles (NPs), including nanocarriers, can transport through the BBB and locate in the central nervous system (CNS). Because the CNS may be a potential target organ of the nanomaterials, it is essential to determine the neurotoxic effects of NPs. In this review, possible dental nanomaterials and their pathways into the CNS are discussed, as well as related neurotoxicity effects underlying the in vitro and in vivo studies. Finally, we analyze the limitations of the current testing methods on the toxicological effects of nanomaterials. This review contributes to a better understanding of the nano-related risks to the CNS as well as the further development of safety assessment systems.
\end{abstract}

Keywords: dental, nanomaterials, central nervous system, toxicity, testing methods, risk assessment

\section{Introduction}

Nanomaterials are defined as materials composed of unbound particles or particles in an aggregate or agglomerate state with one or more external dimensions with a size ranging from $1 \mathrm{~nm}$ to $100 \mathrm{~nm}$. ${ }^{1}$ Such materials possess typical nanostructure-dependent properties (eg, chemical, biological, optical, mechanical, and magnetic), which distinguish them from their bulk counterparts. Because of their new and unique properties, nanomaterials are becoming ubiquitous in various products, such as sunscreens, cosmetics, medical supplies, clothing, and building materials. The global demand for nanomaterials and nano-enabled devices is expected to approach US\$1 trillion by 2015. ${ }^{2}$ The overwhelming increase in the amount of nanotechnology-related products has had major impacts on both society and the environment.

The benefits of nanomaterials to modern medicine have been particularly tremendous. In recent years, nanomaterials have been widely used in the production of dental materials, including light polymerization composite resins ${ }^{3,4}$ and bonding systems, coating materials for dental implants, ${ }^{5}$ bioceramics, endodontic sealers, ${ }^{6}$ and mouthwashes. ${ }^{7}$ However, in addition to yielding significant improvements in clinical 
treatments, the applications of dental nanomaterials have also created growing concerns regarding their biosecurity. Because the nanomaterials are similar in size to DNA molecules, proteins, viruses, and biological molecules, some of their biological effects may lie in the interaction mechanisms between living things and the environment, which has not yet been distinctly understood. In fact, nanoparticles (NPs) are a type of mesoscopic system that possesses a special surface effect, a small size effect, and a macroscopic quantum tunneling effect. When reduced to the nanoscale, many benign materials may exhibit appreciable cellular toxicity. For example, $\mathrm{TiO}_{2}$, a common substrate material for dental implants, was previously classified as being biologically inert in humans and animals and has been used as a negative control particle in a variety of toxicological studies. Nevertheless, several possible adverse effects of $\mathrm{TiO}_{2} \mathrm{NPs}_{\text {on hum health }}$ have been recently discovered. ${ }^{8,9}$ Additionally, in vitro data have also demonstrated the cellular toxicity of zinc oxide nanomaterials (nano- $\mathrm{ZnO}$ ), which have been developed for numerous anti-infection applications. ${ }^{10}$

Indeed, nanomaterials are not inherently benign; they can affect biological behaviors at different levels, including the cellular, subcellular, and protein levels. After exposure, some nanomaterials readily travel throughout the body, deposit in target organs, penetrate cell membranes, lodge in the mitochondria, and trigger injurious responses. In recent years, many studies have demonstrated that nanomaterials can accumulate in the heart, liver, spleen, lungs, and kidneys of animals. ${ }^{11,12}$ The brain is different from other organs, as the blood-brain barrier (BBB) can prevent the majority of substances from entering the brain. However, existing research has shown that nanomaterials have relatively easily crossed the $\mathrm{BBB}$ into the brain, and the crossing of the BBB by nanomaterials was attributed to their small sizes and high surface activities. Furthermore, these nanomaterials may even translocate into the brain by the olfactory and sensory nerves. ${ }^{13,14}$ All of these findings have suggested that the central nervous system (CNS) could be damaged and a range of pathogenic effects may be experienced upon exposure to nanomaterials.

Researchers have conducted many in vivo and in vitro studies to explore the interactions between the nanomaterials and biological macromolecules, cells, organs, and tissues, and the majority of these studies have found that the effects of the biological toxicities of the nanomaterials may be induced by the mechanisms of oxidative stress and inflammatory reactions. ${ }^{15,16}$ However, one problem that has arisen is whether the traditional methods and techniques utilized in the analysis of the toxicities of the nanomaterials are accurate and reliable. Further questions have arisen regarding whether the unique physicochemical properties of the nanomaterials have introduced new mechanisms of injury and whether these new mechanisms will lead to new pathologies. Even if the nanomaterials do not introduce new pathologies, there could be new, novel mechanisms of injury that require special tools, assays, and approaches to assess their toxicities. ${ }^{17}$ Therefore, it is still too early to draw explicit conclusions regarding the inherent dangers of nanomaterials, let alone their exact mechanisms of toxicity.

This review is mainly intended to provide a detailed introduction of the applications of dental nanomaterials along with their potential neurotoxic effects. Possible dental nanomaterials and their pathways into the CNS are stated first, and the neurotoxic effects and related mechanisms behind the in vitro and in vivo studies are further discussed. Finally, we highlight the limitations of the current investigative methods and provide some suggestions on some aspects of future researches. We hope this review will contribute to a better understanding of the nano-related risks to the CNS and the further development of safety assessment systems.

\section{Possible commercial dental nanomaterials}

Alongside the industrialization process of nanotechnology, dental nanomaterials have been widely utilized, and the opportunities for people to come into contact with nanomaterials have improved greatly. Nanotechnology-based materials have led to great improvements in clinical treatments and have driven the innovation of numerous conventional dental materials. Major applications of nanomaterials in the dental field are described in this section, and a summary of these examples is provided in Table 1.

\section{Composite resins and bonding systems}

The matrices of traditional composite resins have generally been comprising various types of inorganic fillers. Applications of nano-sized fillings in the resin matrices have overcome some of the mechanical limitations and have significantly improved their clinical performance. Commonly used nanomaterials include nano-ZnO, ${ }^{3,4}$ nano-silica, ${ }^{18,19}$ nano-calcium phosphate and calcium fluoride (nano- $\mathrm{Ca}_{3}\left(\mathrm{PO}_{4}\right)_{2}$ and $\mathrm{CaF}_{2}$, respectively), ${ }^{20}$ and nano- $\mathrm{TiO}_{2} \cdot{ }^{21}$ In addition to composite resins, the utilization of nanomaterials in dental adhesives has also effectively improved their bonding strengths and mechanical properties. For instance, polyhedral oligomeric silsesquioxanes hybrid nano-composites have polymerized with silicon-based nanomaterials to form a novel type of 
Table I Summary of the current nanomaterials in the dental field

\begin{tabular}{|c|c|c|c|c|}
\hline $\begin{array}{l}\text { Major } \\
\text { applications }\end{array}$ & Nanomaterial type & Particle size & Significant characteristics & References \\
\hline \multirow[t]{5}{*}{ Composite resins } & Nano-ZnO & $125 \mathrm{~nm}$ & $\begin{array}{l}\text { Better antibacterial and mechanical } \\
\text { properties }\end{array}$ & Kasraei et $\mathrm{al}^{3}$ \\
\hline & Nano-silica & $7 \mathrm{~nm}$ & Better mechanical properties & Balos et $\mathrm{al}^{18}$ \\
\hline & & $70 \mathrm{~nm}$ & & Wang et $\mathrm{al}^{12}$ \\
\hline & Nano- $\mathrm{Ca}_{3}\left(\mathrm{PO}_{4}\right)_{2}$ and $\mathrm{CaF}_{2}$ & $\begin{array}{l}112 \mathrm{~nm} \\
53 \mathrm{~nm}\end{array}$ & $\begin{array}{l}\text { Better stress-bearing capabilities } \\
\text { and the inhibition of caries }\end{array}$ & $X u$ et $\mathrm{al}^{20}$ \\
\hline & Nano- $\mathrm{TiO}_{2}$ & $<20 \mathrm{~nm}$ & $\begin{array}{l}\text { Improved microhardness and flexural } \\
\text { strength }\end{array}$ & Xia et $\mathrm{al}^{21}$ \\
\hline \multirow[t]{3}{*}{ Dental adhesives } & Nano-HAp & $20-70 \mathrm{~nm}$ & Better bonding strength to dentin & Wagner et $\mathrm{al}^{24}$ \\
\hline & $\begin{array}{l}\text { Nano-silver and calcium } \\
\text { phosphate }\end{array}$ & $\begin{array}{l}<10 \mathrm{~nm} \\
112 \mathrm{~nm}\end{array}$ & Improved antibacterial properties & Melo et a ${ }^{23}$ \\
\hline & Nano-silica & $7 \mathrm{~nm}$ & $\begin{array}{l}\text { High mechanical strength and good } \\
\text { thermostability }\end{array}$ & $\begin{array}{l}\text { Wang et } \mathrm{al}^{22} ; \\
\text { Habekost et } \mathrm{a}^{25}\end{array}$ \\
\hline Root canal fillings & Nano-HAp & - & $\begin{array}{l}\text { Better osteogenesis and improved } \\
\text { bacteriostatic and antibacterial effects }\end{array}$ & $\begin{array}{l}\text { Jallot et } \mathrm{a}^{26} \\
\text { Krisanapiboon et } \mathrm{al}^{27}\end{array}$ \\
\hline \multirow[t]{2}{*}{$\begin{array}{l}\text { Bone repair } \\
\text { materials }\end{array}$} & Nano-HAp & $\begin{array}{l}100 \mathrm{~nm} \\
20 \mathrm{~nm} \\
3 \mathrm{~nm}\end{array}$ & $\begin{array}{l}\text { Guiding the regeneration of } \\
\text { periodontal and bone tissue }\end{array}$ & $\begin{array}{l}\text { Huber et } \mathrm{al}^{29} ; \\
\text { Qi et } \mathrm{a}^{28} \text {; Yang et al }{ }^{30}\end{array}$ \\
\hline & $\begin{array}{l}\text { Nano-ZrO } / / \mathrm{HAp} \\
\text { composite }\end{array}$ & $\begin{array}{l}70-90 \mathrm{~nm} / \\
500-1,000 \mathrm{~nm}\end{array}$ & Guiding bone reconstruction & An et $\mathrm{al}^{31}$ \\
\hline Bioceramics & $\begin{array}{l}\text { Nano- } \mathrm{ZrO}_{2} / \mathrm{Al}_{2} \mathrm{O}_{3} \\
\text { Nano-silver }\end{array}$ & - & $\begin{array}{l}\text { Better resistance to crack propagation } \\
\text { Increased fracture toughness and } \\
\text { Vickers hardness }\end{array}$ & $\begin{array}{l}\text { De Aza et } \mathrm{al}^{32} \\
\text { Uno et } \mathrm{al}^{33}\end{array}$ \\
\hline $\begin{array}{l}\text { Silicone elastomer } \\
\text { material }\end{array}$ & Nano-Ti-, Zn-, Ce-oxide & $\begin{array}{l}30-40 \mathrm{~nm} \\
20 \mathrm{~nm} \\
50 \mathrm{~nm}\end{array}$ & Improved mechanical properties & Han et $\mathrm{al}^{34}$ \\
\hline $\begin{array}{l}\text { Denture base } \\
\text { materials }\end{array}$ & Nano-silver & $10-20 \mathrm{~nm}$ & $\begin{array}{l}\text { Better antifungal properties and } \\
\text { biocompatibility }\end{array}$ & Acosta-Torres et a ${ }^{35}$ \\
\hline \multirow[t]{4}{*}{$\begin{array}{l}\text { Coating materials } \\
\text { for dental implants }\end{array}$} & Nano-porous alumina & $20-200 \mathrm{~nm}$ & $\begin{array}{l}\text { Good cell adhesion and no adverse } \\
\text { effect on cell activity }\end{array}$ & Karlsson et al ${ }^{36}$ \\
\hline & $\begin{array}{l}\text { Nano-zirconia/calcium } \\
\text { phosphate }\end{array}$ & $360 \mathrm{~nm} / 15 \mathrm{I} \mathrm{nm}$ & $\begin{array}{l}\text { High bioactivity potential and good } \\
\text { mechanical stability }\end{array}$ & Pardun et $\mathrm{a}^{37}$ \\
\hline & Nano-ZnO & $10-100 \mathrm{~nm}$ & $\begin{array}{l}\text { Better antimicrobial and biocompatible } \\
\text { properties }\end{array}$ & Memarzadeh et $\mathrm{a}^{5}$ \\
\hline & Nano-HAp & - & Achieving rapid osseointegration & Uezono et $\mathrm{al}^{38}$ \\
\hline \multirow[t]{2}{*}{ Drug delivery } & Nano-silica & $150 \mathrm{~nm}$ & $\begin{array}{l}\text { Sustained and controlled release of } \\
\text { anticancer drugs (as drug carriers) }\end{array}$ & Lebold et a ${ }^{40}$ \\
\hline & $\begin{array}{l}\text { Polymeric NPs (vitamin E } \\
\text { TPGS) }\end{array}$ & $300-1,000 \mathrm{~nm}$ & $\begin{array}{l}\text { Controlled release of anticancer drugs } \\
\text { (as drug carriers) }\end{array}$ & Mu and Feng ${ }^{41}$ \\
\hline Tumor imaging & $\begin{array}{l}\text { Superparamagnetic iron } \\
\text { oxide NPs }\end{array}$ & $82 \pm 4.4 \mathrm{~nm}$ & $\begin{array}{l}\text { Good superparamagnetic and optical } \\
\text { properties }\end{array}$ & Melancon et $\mathrm{al}^{42}$ \\
\hline
\end{tabular}

Abbreviations: HAp, hydroxyapatite; NPs, nanoparticles; TPGS, d-alpha-tocopheryl polyethylene glycol 1000 succinate.

bonding material that possessed a large mechanical strength and good thermostability. ${ }^{22}$ Furthermore, the antibacterial properties of the bonding agents could be greatly improved by the inclusion of nano-sized silver and calcium phosphate..$^{23}$ Other possible additions have included nano-hydroxyapatite $(\text { nano-HAp) })^{24}$ and nano-silica. ${ }^{25}$

\section{Root filling materials}

Root canal filling materials are supposed to effectively kill the bacteria in the periodical lesions, densely seal the apical zones, and promote healing. However, the brittleness of the root canal often increases after treatment due to the large size of the traditional HAp. The mismatch of the elastic modulus between the root dentin and fillings has also resulted in percolation. In contrast, nano-HAp represents a unique advantage in this aspect because its structure is similar to natural inorganic bone. Nano-HAp was able to induce osteogenesis ${ }^{26}$ and further improve the bacteriostatic and antibacterial effects of the root fillings. ${ }^{27}$ Considering its good bioactivity, nano-HAp was also used as an optimum 
replacement material in the repair of bone defects. ${ }^{28,29}$ For example, Yang et $\mathrm{al}^{30}$ demonstrated that nano-HAp-coated silk scaffolds effectively guided the regeneration of periodontal and bone tissue. Similarly, porous $\mathrm{ZrO}_{2} / \mathrm{HAp}$ composite scaffolds were also reported to possess excellent mechanical properties and cellular/tissue compatibilities. ${ }^{31}$

\section{Bioceramics and associated dental prosthesis}

Nanostructured bioceramics, which are constructed by a plasma-coating or chemical deposition process, generally possess enhanced mechanical properties, such as a better resistance to crack propagation ${ }^{32}$ and an increased fracture toughness and Vickers hardness. ${ }^{33}$ Additionally, the utilization of nano-sized Ti-, Zn-, and Ce-oxide has greatly improved the mechanical properties of a maxillofacial silicone elastomer. ${ }^{34}$ Nano-sized silver may be an effective addition to denture-based materials to improve their antifungal properties and biocompatibility. ${ }^{35}$ Thus, the applications of nanomaterials have the potential to effectively improve the comprehensive properties, including the mechanical, chemical, and biological properties, of different types of conventional dental materials.

\section{Coating materials for dental implants}

Good osseointegration at the implant-bone interface is essential for the success of dental implantation, but, unfortunately, this still remains a significant challenge. In recent years, a number of studies have reported the increased success rates of implants through the applications of a nano-coating on the surface, a nano-ceramic, and artificial nano-bone materials. For example, nano-porous alumina, ${ }^{36}$ nano-zirconia/ nano- $\mathrm{Ca}_{3}\left(\mathrm{PO}_{4}\right)_{2},{ }^{37}$ nano- $\mathrm{ZnO},{ }^{5}$ and nano-HAp ${ }^{38}$ have been utilized to increase the surface bioactivities of dental implants to achieve superior osseointegration. The advantages of the nanoscale modifications of dental implant surfaces have been presented in a recent review by Mendonca et al. ${ }^{39}$

\section{Target delivery and imaging in tumor chemotherapy}

A key problem in the use of chemotherapy for oral malignant tumors is how to improve the local concentrations of the drug while reducing the systemic side effects. To solve this problem, novel NP-based drug delivery strategies have been studied where the NPs are the drug carriers that can transport the anticancer drugs to the tumor sites, which further increases the therapeutic efficacy. For example, Lebold et $\mathrm{al}^{40}$ applied mesoporous thin silica films with nanoscale pores as drug carriers that were incorporated with doxorubicin, a widely used anticancer drug. The mesoporous silica nanomaterials demonstrated a sustained and controlled release of the anticancer drugs. Mu and Feng $^{41}$ discussed the advantages of manufacturing polymeric NPs (vitamin E d-alpha-tocopheryl polyethylene glycol 1000 succinate) for the controlled release of paclitaxel and other anticancer drugs. Another application of targeted therapy with novel NPs involves tumor imaging. Superparamagnetic iron oxide with special surface modifications has been utilized to guide the laser ablation of maxillofacial cancer because these manufactured NPs are magnetic resonance-active and can be selectively heated up for simultaneous imaging. ${ }^{42}$ Similarly, liposomal nanocarriers also possess special advantages in their use for tumor radiography and imaging due to their good encapsulation of drugs and gadolinium. ${ }^{43}$

Aside from the aforementioned therapeutic uses, many nanomaterials, such as nano- $\mathrm{TiO}_{2}$ and nano- $\mathrm{ZnO}$, have been utilized in everyday dental items, including toothpastes and mouthwashes. ${ }^{7,44}$ Considering the various applications of dental nanomaterials listed above, we should admit the outstanding contributions of nanomaterials to modern medicine. In the meantime, however, the risks of nanomaterials to human health have also significantly increased accompanied with more exposure opportunities.

\section{Possible pathways for entering the CNS}

Based on the principles of toxicology, nearly all substances are potentially toxic to humans, and the key lies in the dose and method of exposure. The people who most likely come into contact with dental nanomaterials are the production, research, and development staff, as well as the dental staff and patients. In clinical situations, most of the dental nanomaterials were directly applied in the oral cavity or maxillofacial region, allowing the nanomaterials to easily enter into the bloodstream (or lymph fluid) via absorption through oral mucosa or through the digestive tract after swallowing. In addition, opportunities for exposure to nanomaterials may also occur with the utilization of dental tools. At present, tungsten carbide (WC) nanowires, which are a new form of nano-WC, have been applied in the production of carbide micro-drills, including in dental drills and burrs. Thus, dental staff and patients may face abrasive NPs directly during a grinding or polishing process, especially considering that many dental prosthetic materials also contain nano-metals (eg, $\mathrm{Co}, \mathrm{Cr}, \mathrm{Au}, \mathrm{Ag}, \mathrm{Ti}$ ), resins (Si), and ceramics (eg, Zr, $\mathrm{Al}, \mathrm{Li}, \mathrm{Mg}, \mathrm{Fe}$ ). Once these NPs are absorbed into our bloodstreams, they can be distributed to different organs, including 
the liver, spleen, kidneys, heart, lungs, and brain. Compared with the other organs, these substances are still required to cross the BBB or blood-cerebrospinal fluid (CSF) barriers to reach the brain. In addition to the systemic pathways, nanomaterials can directly translocate to the brain via nerves. ${ }^{45}$ The possible pathways of dental nanomaterials entering the CNS are described below.

\section{BBB pathway}

The BBB is mainly composed of the cerebrovascular endothelium, which is sealed with tight junctions (TJs). Additional structures, such as pericytes, astrocyte end-feet, and a discontinuous basal membrane, are supportive cells to the BBB. All of these structures associated with the surrounding neurons constitute a complex and functional "neurovascular unit" 46 (Figure 1). The unique structural characteristics of the BBB are the intracellular TJs and the absence of Weibel-Palade bodies, which are significantly different from other vascular endothelial cells and can prevent most of the substances from entering into the CNS. In addition to these physical barriers, the BBB also possesses some metabolic barriers to the delivery of therapeutic agents. ${ }^{47}$ First, the endothelia of the $\mathrm{BBB}$ are deficient in pinocytic vesicles, and thus, they can only allow for the low pinocytosis of certain substrates. Second, a series of intra- and extracellular enzymes that are expressed by the cellular components will limit the transport of a substance through the BBB. The complex interactions between the drugs and these enzyme systems often lead to therapeutic failure. Finally, efflux systems (such as P-glycoprotein) of the endothelial cells also play an important role in the elimination of harmful endogenous and exogenous molecules. Another associated structure that serves to prevent potentially harmful substances from entering the brain is known as the blood-CSF barrier. ${ }^{48}$ This barrier is formed by choroid plexus epithelial cells, which possess similar TJs but a smaller surface area compared with the BBB endothelia. The blood-CSF barrier helps to prevent macromolecules from penetrating into the CSF, and this function is further reinforced by the active transport systems, which actively remove therapeutic organic acids from the CSF. ${ }^{49}$

Despite these limitations, many studies have shown that nanomaterials, including nanomaterials that have been utilized as drug carriers, can cross the BBB (or blood-CSF barrier) into the CNS. ${ }^{50-52}$ Therefore, nanotechnology-based carriers have been exploited as an effective approach for drug delivery in the CNS. At present, the majority of the strategies described for the passage of nanomaterials (as drug carriers) through the BBB involve the mechanisms shown in Figure 2, which include the following: 1) NPs help to enable drugs to penetrate the $\mathrm{BBB}$ by opening the TJs between the endothelial cells; 2) NPs are transcytosed through the endothelial cell layer; 3) NPs are endocytosed by the endothelial cells and release the drug inside the cell; 4) coating agents of NPs, such as polysorbates, inhibit the transmembrane efflux systems; and 5) NPs may induce local toxic effects on the brain vasculature, leading to a limited increase in the permeability of the neural endothelial cells. ${ }^{53,54}$

Under certain conditions, the brain is more vulnerable to dental nanomaterials when the exposure occurs in its developmental stage. Many facts indicate that the structure

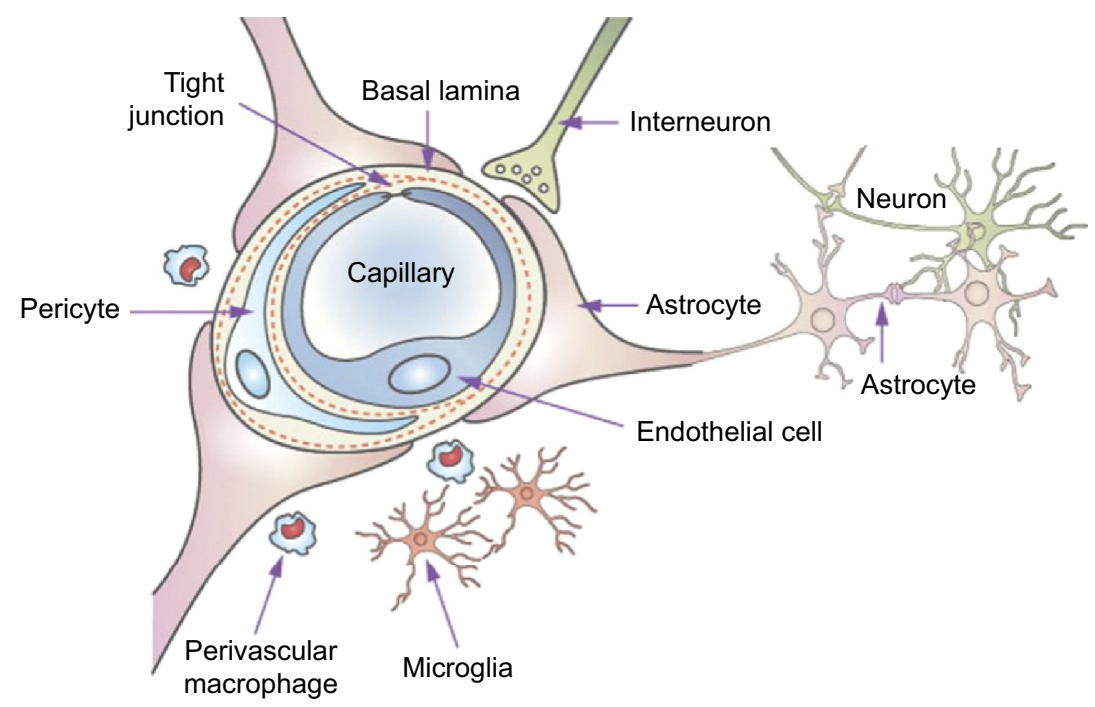

Figure I Schematic of the blood-brain barrier and the associated components of the neurovascular unit.

Note: Reprinted from Adv Drug Deliv Rev, 64(7), Chen Y, Liu L. Modern methods for delivery of drugs across the blood-brain barrier. 640-665., Copyright (2012), with permission from Elsevier. ${ }^{46}$ 


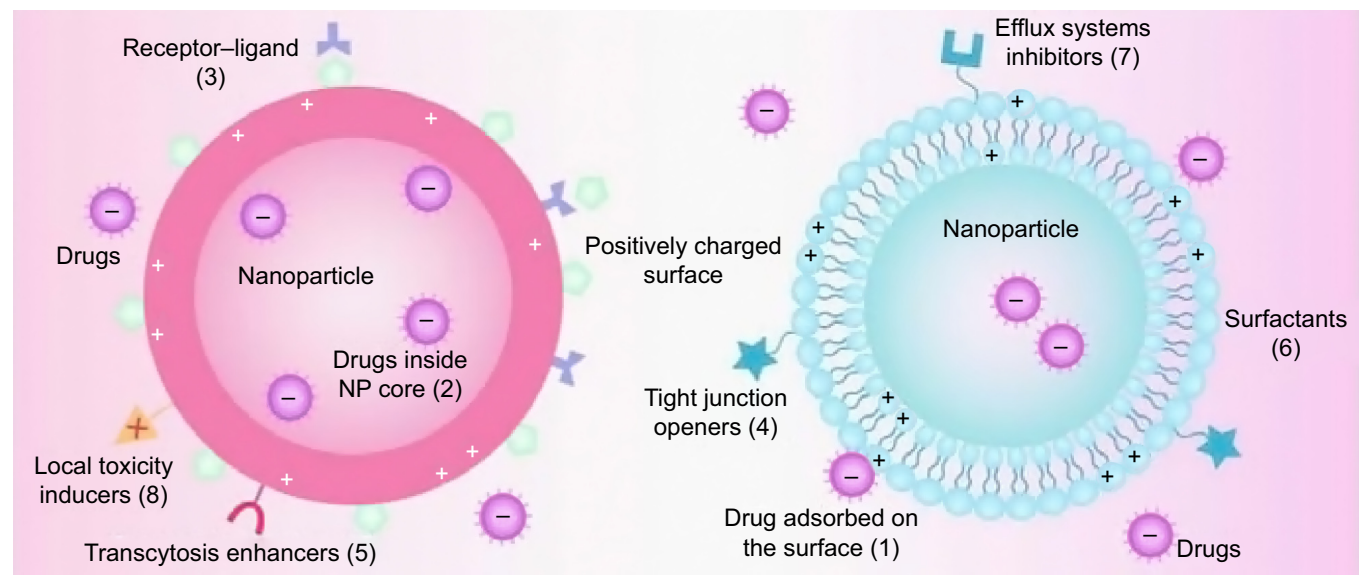

Figure 2 Schematic representation of multifunctional NPs as drug carriers across the BBB.

Notes: Drugs can be adsorbed onto the surface of the NP due to the interactions between positive and negative charges (I) and may even be trapped inside its core (2). Different strategies have been applied for the transportation of drugs across the BBB: receptor-ligands for unique recognition and endocytosis (3); tight junction openers for improved intercellular penetration (4); transcytosis enhancers for the promotion of the transport of NP across the membranes (5); surfactants for the enhancement of membrane fluidization (6); efflux system inhibitors for the reduction of drug efflux (7); and local toxicity inducers for the increase in the permeability of the endothelial cells (8). Reproduced with permission of Informa Healthcare. Barbu E, Molnar E, Tsibouklis J, Gorecki DC. The potential for nanoparticle-based drug delivery to the brain: overcoming the blood-brain barrier. Expert Opin Drug Deliv. 6(6):553-565, copyright (C) 2009, Informa Healthcare. ${ }^{53}$

Abbreviations: NP, nanoparticle; BBB, blood-brain barrier.

and function of the BBB mature stage by stage alongside the ontogenesis of animals. Consequently, compared with adult brains, fetal brains may be more easily affected by blood-borne substances, including nanomaterials, because the development of the BBBs in the fetal brains is incomplete. ${ }^{55}$ Yamashita et al ${ }^{56}$ found that nano-silica and nano- $\mathrm{TiO}_{2}$ caused complications with the pregnancy when they were injected intravenously into pregnant mice. These NPs accumulated in the placenta, fetal brain, and fetal liver. Other toxicity studies have also shown that the nanomaterials could cross the placental barriers in pregnant mice and thereafter cause neurotoxicity effects in the offspring. ${ }^{9,57}$ Thus, special attention must be given to the utilization of dental nanomaterials in pregnant patients, especially early on in their pregnancy.

Although numerous studies have examined the mechanisms of NPs that have been transported through the BBB, the mechanisms have still not been fully elucidated, partially due to the special high doses that have been applied in vitro and may not be achieved under in vivo conditions. Furthermore, there is still the unresolved question of whether the NPs that do cross the BBB localize in the brain parenchyma, enter the endothelial cells of the CNS vasculature, or both. These questions must be further studied.

\section{Sensory nerve translocation pathway}

The olfactory pathway consists of the olfactory epithelium, olfactory tract, anterior olfactory nucleus, piriform cortex, amygdala, and hypothalamus. This pathway can be the major route for the CNS delivery of therapeutic agents following intranasal administration. There is a large amount of evidence that indicated that inhaled or intranasally instilled NPs can enter into the CNS via the olfactory epithelium and its associated neurons, pass directly into the olfactory lobes of the brain, and then induce significant inflammation-related effects. ${ }^{58-60}$ This route involves the olfactory or trigeminal nerve systems, which are initiated from parts of the brain and terminate in the nasal cavity at the olfactory epithelium or respiratory epithelium, all of which bypass the BBB. ${ }^{61}$ Other studies have attempted to focus on the nerve conduction velocity in nanomaterials. For example, De Lorenzo ${ }^{62}$ reported that gold NPs $(50 \mathrm{~nm}$ in size) were translocated by the olfactory nerve after nasal administration in the squirrel monkey, and the transfer speed was $2.5 \mathrm{~mm} /$ hour. However, in this research, the damage to the nerve fibers and the impacts on the normal neurons and neural functions in the process of the translocation were not further investigated.

Additionally, an often overlooked but important pathway connecting the nasal passages to the CNS involves the trigeminal nerve, which innervates the respiratory and olfactory epithelium of the nasal passages. Three branches of the trigeminal nerve (ophthalmic division, maxillary division, and mandibular division) merge at the trigeminal ganglion, enter the CNS at the pons, and terminate in the spinal trigeminal nuclei in the brainstem ${ }^{63}$ Considering that a small portion of the trigeminal nerve also terminates in the olfactory bulbs, cross talk between the trigeminal and olfactory routes of the drug delivery to the brain may occur. 
Thus, it is often difficult to determine whether intranasally administered drugs reach the olfactory bulb and other rostral brain areas through the trigeminal or olfactory pathways or if both are involved. ${ }^{64}$

However, due to anatomical and physiological differences, the sensory nerve uptake of NPs proposed in the rat model may not be adequately predictive of human exposure..$^{13,65}$ The translocation of NPs via the human olfactory nerve pathways into the brain is more difficult than that of rats, and the amounts involved in the translocation are also considerably lower. However, this does not exclude the possibility of the utilization of the nerve pathway in humans. Oberdorster et $\mathrm{al}^{65}$ once reported that the translocation of $20 \mathrm{~nm}$ particles is two to ten times higher in the human olfactory bulb than in rats. According to the limited data that are available, it is still difficult to evaluate the extent of the accumulation in the brain through axonal transport, although it is a realistic possibility. More importantly, future research should consider additional aspects, such as the evaluation of the mechanisms of NP uptake and axonal translocation, the changes of NP surface chemistry during neuronal transport, and the distribution kinetics and elimination pathways in the CNS.

\section{In vivo studies on the potential toxicity of nanomaterials on the CNS NP exposure via different drug delivery routes}

In clinical situations, nanomaterials are able to enter the body via different routes. For instance, materials utilized in bone repair, periodontal dressing pastes, root canal pastes, and implant surface coatings can be visibly contaminated with blood, thus allowing NPs to rapidly enter the bloodstream in the short term and eventually reach the CNS via transport across the BBB. Furthermore, when materials are being mechanically ground and polished in the clinic or laboratory, particles of the dental restorative materials may spread in the air and enter the CNS via pulmonary inhalation or along the olfactory/trigeminal nerve translocation pathways. Finally, the abrasion and dissolving process of nano-fillings and restorative materials and the usage of toothpastes and mouthwashes may all lead to the NP exposure in the oral mucosa, as well as further absorption in the gastrointestinal tract after swallowing. Here, we focus on the main pathways through which nanomaterials enter the CNS. A summary of the examples found in this manuscript is presented in Table 2 .
In a recent study performed by Vilella et al, ${ }^{66}$ the author found that NPs were widely distributed across the regions of the brain 6 hours after the intraperitoneal injection on C57B16 mice (Figure 3). This finding was further confirmed by the results from another toxicity study ${ }^{67}$ in which zinc concentrations in rat brains increased significantly after an intravenous injection of a suspension of ZnO NPs for 14 consecutive days. The study also found that the concentration of neurotransmitters in the brain, such as norepinephrine and epinephrine, remained unchanged. This observation suggested that the acute intravenous injection of $\mathrm{ZnO}$ NPs may not affect neurotransmitter concentrations in adult rats. In contrast, in Zhang et al's study, ${ }^{68}$ a significant upregulation of Ti particles in the cerebral cortex and striatum was reported when mice were intranasally instilled with different types of $\mathrm{TiO}_{2} \mathrm{NPs}$; this caused clear morphological changes in the neurons and created a significant disturbance in the monoamine neurotransmitter levels. This research highlighted the important role of the surface modification of the NPs in their neurotoxicity. In fact, nanomaterials with the same chemical compositions differed in their toxicological properties according to their shapes, sizes, surface charges, types of coating material, and reactivities. ${ }^{69}$

Li et al ${ }^{70}$ examined the potential systematic influences of $\mathrm{TiO}_{2}$ NPs on mice following a 4-week intratracheal instillation. Their results indicated that $\mathrm{TiO}_{2} \mathrm{NPs}$ could transfer through the $\mathrm{BBB}$ and thereafter induce an injury to the brain by the activation of oxidative stress responses. In another toxicity study of $\mathrm{TiO}_{2}$ NPs in mice performed by Ze et $\mathrm{al}^{71} \mathrm{TiO}_{2}$ NPs were translocated and accumulated in the brain through nasal administration, and this led to an oxidative stress and a series of pathological changes, such as an overproliferation of the glial cells and hippocampal cell apoptosis. The authors further noted some significant changes in genes that may be potential biomarkers of brain toxicity. Similar findings were also reported by Kwon et $\mathrm{al}^{72}$ who found that $\mathrm{Al}$ NPs exposure modulated the gene and protein expressions of mitogen-activated protein kinases and their activities. Marano et $\mathrm{al}^{73}$ recently discussed the NP-induced reactive oxygen species (ROS) generation and activation of signaling pathways involving various protein kinases.

A recent in vivo study ${ }^{74}$ investigated the toxic effects of nano- $\mathrm{TiO}_{2}$, nano- $\mathrm{ZnO}$, and nano- $\mathrm{Al}_{2} \mathrm{O}_{3}$ in mice through oral exposure $(500 \mathrm{mg} / \mathrm{kg})$ for 21 consecutive days. These NPs produced a significant oxidative stress in the brain, as evident from the enhanced levels of ROS and the altered activities of the antioxidant enzymes. These changes were also supported by the inhibition of CuZnSOD and MnSOD, which are 
Table 2 Neurotoxicity effects of dental nanomaterials under in vivo conditions

\begin{tabular}{|c|c|c|c|c|c|}
\hline Drug delivery routes & $\begin{array}{l}\text { Nanomaterial } \\
\text { type }\end{array}$ & Particle size & $\begin{array}{l}\text { Exposure } \\
\text { model }\end{array}$ & Neurotoxicity effects & References \\
\hline Intravenous injection & Nano-ZnO & $30-40 \mathrm{~nm}$ & Wistar rats & $\begin{array}{l}\text { Increased brain zinc } \\
\text { concentrations }\end{array}$ & Amara et $\mathrm{al}^{67}$ \\
\hline Intraperitoneal injection & G7 NPs & $170 \pm 18 \mathrm{~nm}$ & C57BI6 mice & $\begin{array}{l}\text { Accumulation in brain areas } \\
\text { and special cell populations }\end{array}$ & Vilella et $\mathrm{al}^{66}$ \\
\hline Intranasal instillation & Nano- $\mathrm{TiO}_{2}$ & $\begin{array}{l}40 \mathrm{~nm} \\
50 \mathrm{~nm}\end{array}$ & ICR mice & $\begin{array}{l}\text { Morphological changes } \\
\text { of neurons } \\
\text { Disturbance of monoamine } \\
\text { neurotransmitter levels }\end{array}$ & Zhang et $\mathrm{al}^{68}$ \\
\hline Intratracheal instillation & Nano- $\mathrm{TiO}_{2}$ & $3 \mathrm{~nm}$ & Kunming mice & $\begin{array}{l}\text { Brain injury by inducing } \\
\text { oxidative stress responses }\end{array}$ & Li et $\mathrm{al}^{70}$ \\
\hline Nasal administration & Nano- $\mathrm{TiO}_{2}$ & $5-6 \mathrm{~nm}$ & ICR mice & $\begin{array}{l}\text { Oxidative stress in brain } \\
\text { Pathological changes } \\
\text { of brain cells } \\
\text { Changes in genes associated } \\
\text { with brain toxicity }\end{array}$ & Ze et $\mathrm{al}^{71}$ \\
\hline Nasal instillation & Al NPs & $5-100 \mathrm{~nm}$ & SD rats & $\begin{array}{l}\text { Alteration of gene and } \\
\text { protein expression } \\
\text { of MAPK and their activity }\end{array}$ & Kwon et $\mathrm{al}^{72}$ \\
\hline Oral exposure & $\begin{array}{l}\text { Nano- } \mathrm{TiO}_{2} \\
\text { Nano- } \mathrm{ZnO} \\
\text { Nano- }-\mathrm{Al}_{2} \mathrm{O}_{3}\end{array}$ & $\begin{array}{l}<75 \mathrm{~nm} \\
<100 \mathrm{~nm} \\
45 \mathrm{~nm}\end{array}$ & $\begin{array}{l}\text { Swiss albino } \\
\text { mice }\end{array}$ & Oxidative stress in brain & Shrivastava et $\mathrm{al}^{74}$ \\
\hline Intragastric administration & Nano- $\mathrm{TiO}_{2}$ & $6-7 \mathrm{~nm}$ & ICR mice & $\begin{array}{l}\text { Accumulation of ROS in the } \\
\text { hippocampus } \\
\text { Effects on animal behavior }\end{array}$ & Hu et $\mathrm{a}^{75}$ \\
\hline \multirow[t]{2}{*}{ Intraperitoneal injection } & $\begin{array}{l}\text { Fullerene } \mathrm{C} 60 \\
\text { nanocrystals }\end{array}$ & $100 \mathrm{~nm}$ & SD rats & $\begin{array}{l}\text { Enhanced LTP and spatial } \\
\text { memory }\end{array}$ & Chen et a ${ }^{80}$ \\
\hline & Nano-ZnO & $20-80 \mathrm{~nm}$ & Wistar rats & $\begin{array}{l}\text { Damaged spatial cognition } \\
\text { capability via over-enhanced } \\
\text { LTP }\end{array}$ & Han et $\mathrm{al}^{81}$ \\
\hline Intracerebral injection & Nano- $\mathrm{MnO}_{2}$ & $10 \mathrm{~nm}$ & SD rats & $\begin{array}{l}\text { Alteration of spatial learning } \\
\text { abilities associated with } \\
\text { dopaminergic neuronal } \\
\text { dysfunction }\end{array}$ & Li et a $\left.\right|^{82}$ \\
\hline $\begin{array}{l}\text { Intracerebroventricular } \\
\text { injection }\end{array}$ & Nano- $\mathrm{TiO}_{2}$ & $9 \mathrm{~nm}$ & SD rats & $\begin{array}{l}\text { Induction of malaise and } \\
\text { general motor retardation }\end{array}$ & Kim et $\left.a\right|^{83}$ \\
\hline Intravenous injection & Nano- $\mathrm{TiO}_{2}$ & $5 \mathrm{~nm}$ & SD rats & $\begin{array}{l}\text { Oxidative damage on } \\
\text { the offspring brain and } \\
\text { depressive-like behaviors in } \\
\text { adulthood }\end{array}$ & Cui et $\mathrm{al}^{84}$ \\
\hline Intraperitoneal injection & Nano- $\mathrm{TiO}_{2}$ & $5 \mathrm{~nm}$ & Wistar rats & $\begin{array}{l}\text { Impaired spatial recognition } \\
\text { memory }\end{array}$ & Hu et $a^{89}$ \\
\hline
\end{tabular}

Abbreviations: G7 NPs, glycopeptides-modified poly-lactide-co-glycolide NPs; NPs, nanoparticles; SD, Sprague-Dawley; MAPK, mitogen-activated protein kinases; ROS, reactive oxygen species; LTP, long-term potentiation; ICR, Institute of Cancer Research.

considered important biomarkers of oxidative stress. These observations were consistent with another set of research on the toxicity of $\mathrm{TiO}_{2} \mathrm{NPs}$ that was conducted 2 years earlier by $\mathrm{Hu}$ et $\mathrm{al}^{75}$ this research also indicated that $\mathrm{TiO}_{2}$ NPs induced an accumulation of ROS in the mouse hippocampus. Similar studies of the oxidative stresses that are associated with selective gene expression analyses and immunological biomarkers would further improve our understanding of the mechanisms of neuroinflammation and neurodegeneration associated with NPs. ${ }^{76}$ These results suggested that the involvement of oxidative stress was one of the main mechanisms involved in the NP-induced toxic manifestations. Other possible NPinduced neurotoxicity mechanisms include inflammatory reactions,${ }^{77}$ mitochondrial abnormalities,${ }^{78}$ and apoptosis and autophagy dysfunctions. ${ }^{79}$

\section{Neurotoxic effects associated with animal behavior}

The impact of nanomaterials on animal behavior has received considerable attention in recent years. Activity-dependent 

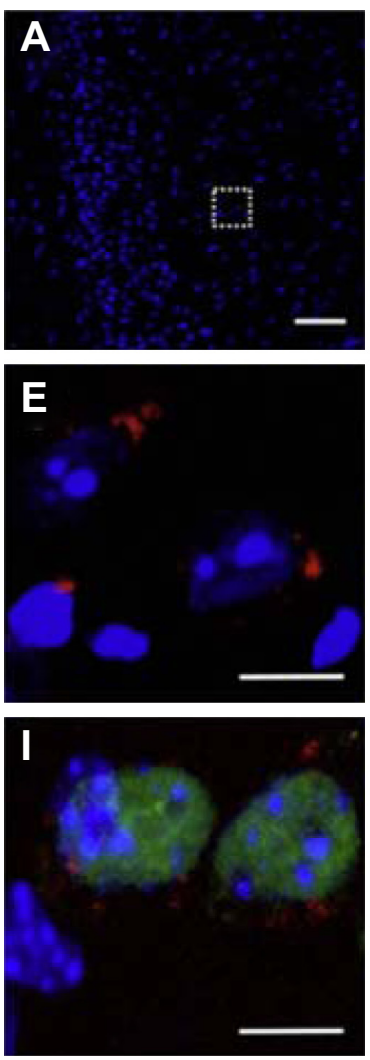
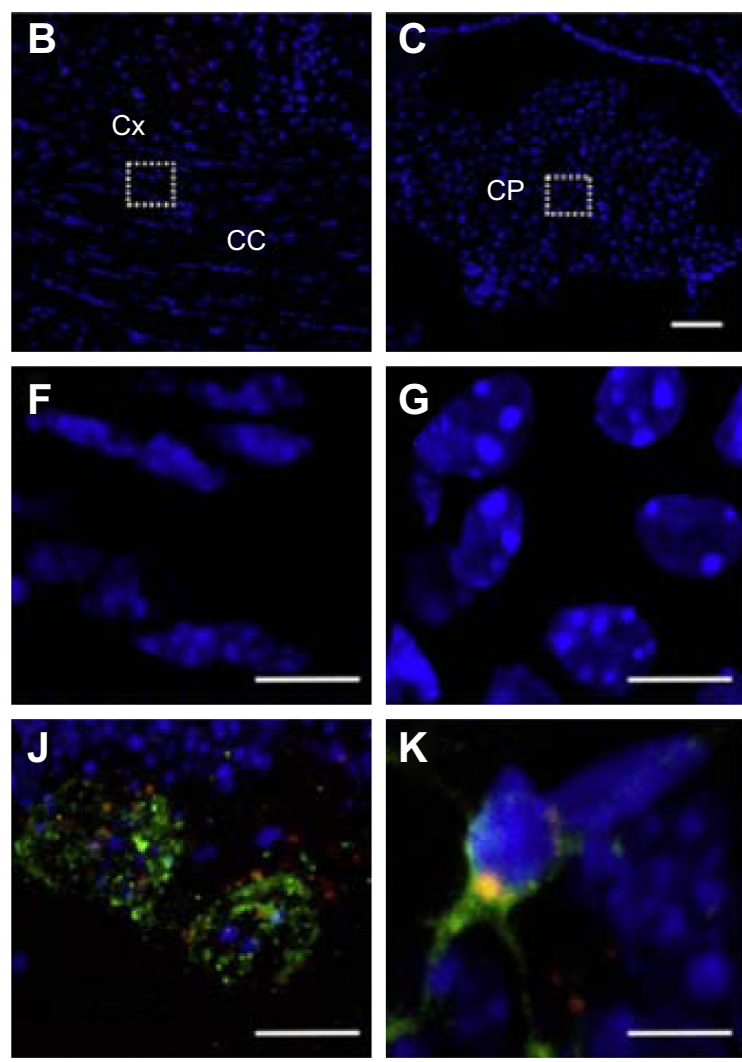
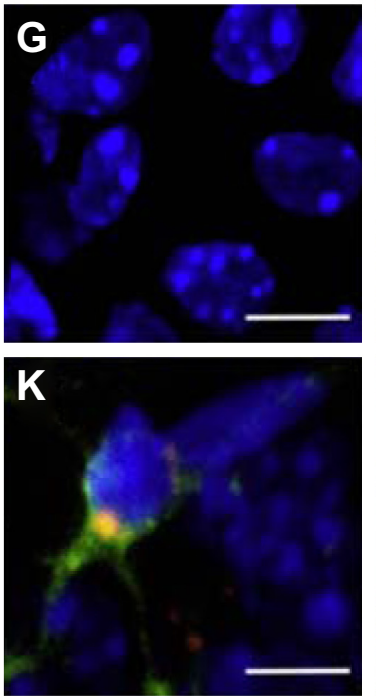
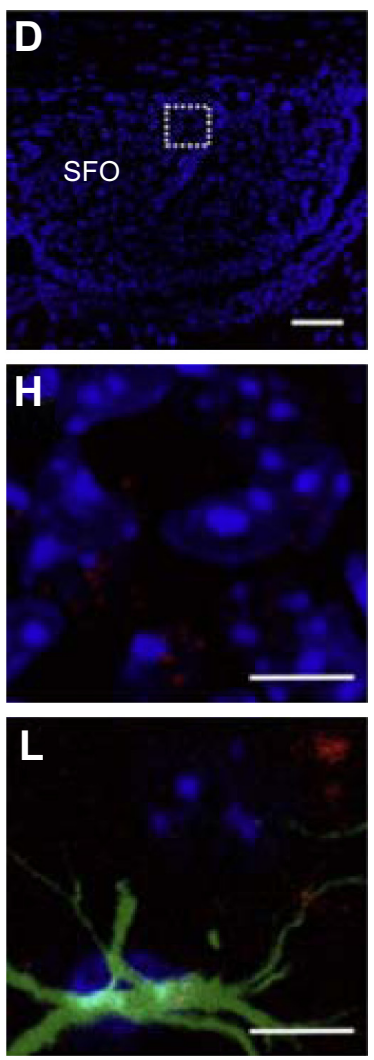

Figure 3 G7 NP distribution in different brain regions and cell populations.

Notes: Confocal microscopy images of brain cryosections in mice sacrificed 6 hours after an intraperitoneal injection of G7 NPs labeled with DAPI (blue), G7 NPs (red), and a number of antibodies (green) Low- (A-D) and high-magnification (E-H) images of the cerebral cortex (A and $\mathbf{E})$, corpus callosum (B and $\mathbf{F})$, choroid plexus (C and $\mathbf{G})$, and subfornical organ $(\mathbf{F}$ and $\mathbf{H})$. (E-H) High-magnification images of the dashed squares indicated in (A-D). (I-L) High-magnification images showing single cells from the hippocampal formation. ${ }^{66}$ Scale bar $=50 \mu \mathrm{m}(\mathbf{A}-\mathbf{D})$ and $10 \mu \mathrm{m}(\mathbf{E}-\mathbf{L})$. Reprinted from J Control Release, I74, Vilella A, Tosi G, Grabrucker AM, et al. Insight on the fate of CNS-targeted nanoparticles. Part I: Rab5-dependent cell-specific uptake and distribution. 195-201., Copyright (2014), with permission from Elsevier.66

Abbreviations: NP, nanoparticle; G7 NPs, glycopeptides-modified poly-lactide-co-glycolide NPs; DAPI, 4',6-diamidino-2-phenylindole.

synaptic changes, generally termed synaptic plasticity (such as long-term potentiation - LTP), are involved in multiple forms of cognitive functions, including learning and memory. The facilitation or stabilization of synaptic plasticity events may lead to a potential improvement of cognitive functions under pathological and even physiological conditions. Chen et $\mathrm{al}^{80}$ reported that intraperitoneal injections of fullerene (C60) nanocrystals (Nano C60) enhanced the LTPs and spatial memories of rats. In contrast, in Han et al's report, ${ }^{81}$ although the LTPs of 4-week-old rats were significantly enhanced, their escape latency in a Morris water maze was prolonged. The authors indicated that the bidirectional effect on long-term synaptic plasticity broke the balance between the stability and flexibility of cognition. This finding was consistent with a more recent study on the toxicity of nano$\mathrm{MnO}_{2}$ conducted by Li et al. ${ }^{82}$ In addition to an influence on the learning ability of animals, research has also highlighted the toxic effects of nanomaterials on the emotion-related behavior of adult animals. For example, Kim et $\mathrm{al}^{83}$ examined the effects of $\mathrm{TiO}_{2}$ NPs on the complex behavior of male rats following an intracerebroventricular injection. In the study, they observed the induction of malaise and general motor retardation of rats. Another toxicity study performed by Cui et al ${ }^{84}$ attempted to evaluate the impact of prenatal exposure to $\mathrm{TiO}_{2}$ NPs on the development of the brains of offspring. The authors found that fetal life stress resulting from prenatal exposure to $\mathrm{TiO}_{2}$ NPs led to depressive-like behaviors in adult rats.

Moreover, there is evidence of the role of ROS in neuronal apoptosis, a key mechanism in brain development. ${ }^{85}$ Nox2-derived ROS generation may contribute to the LTP and memory function. ${ }^{86}$ The brain is particularly vulnerable to oxidative stress because of its high energy demands, low levels of antioxidants, and high cellular concentrations of proteins and lipids. Thus, the impairment of behaviors in animals after nanomaterial exposure may largely result from the overproduction of ROS. Additionally, ROS can regulate neuronal ion channels, kinases, and transcription factors, ${ }^{87,88}$ all of which are considered important factors in brain function. Some other studies have revealed the influence of 
nanomaterials on the levels of neurotransmitters that were associated with memory and learning behaviors. ${ }^{57,89}$

\section{Neurotoxicity of nanomaterials on in vitro cells}

In the brain, the NPs are in contact with three different cell types $^{90}$ : (1) BBB (specialized endothelium) and/or bloodliquid barrier cells (choriplexus endothelium between blood and CSF); (2) glial cells or neuroglia (macroglia: astrocytes and oligodendrocytes; microglia: pericytes regulating $\mathrm{BBB}$ functionality $)^{91}$ and precursors for macrophage-like cells; and (3) two general types of neurons (with [white matter] or without [gray matter] a myelin sheath). Different cell models will be described in this section, and key examples are given in Table 3 .

\section{Neurotoxicity on the in vitro BBB model}

In recent years, nanomaterials have been reported to be able to overcome the $\mathrm{BBB}$ and to produce biologic effects on the CNS. ${ }^{92,93}$ In many situations, the microvascular endothelial cells of the human brain are used as an in vitro BBB model, such as hCMEC/D3 cells, ${ }^{94}$ human brain microvascular endothelial cells, ${ }^{95}$ and human cerebral endothelial cells. ${ }^{96}$ Rat is another common experimental animal due to its availability

Table 3 In vitro studies of dental nanomaterials with different cell models

\begin{tabular}{|c|c|c|c|c|c|}
\hline $\begin{array}{l}\text { Exposure } \\
\text { model }\end{array}$ & Nanomaterial type & $\begin{array}{l}\text { Particle } \\
\text { size }\end{array}$ & Cell type & Main research contents & References \\
\hline \multirow[t]{7}{*}{ BBB } & $\begin{array}{l}\text { Nano-silica } \\
100 \mathrm{~nm} \\
200 \mathrm{~nm}\end{array}$ & $50 \mathrm{~nm}$ & $\begin{array}{l}\text { hCMEC/D3 } \\
\text { cells }\end{array}$ & $\begin{array}{l}\text { Cellular accumulation and } \\
\text { transcytosis conditions of NPs } \\
\text { in brain }\end{array}$ & Ye et $\mathrm{al}^{94}$ \\
\hline & Nano- $\mathrm{TiO}_{2}$ & $21 \mathrm{~nm}$ core & HCECs & $\begin{array}{l}\text { Cellular uptake and localization, } \\
\text { generation of oxidative stress, and } \\
\text { DNA-damaging effects in HCECs }\end{array}$ & $\begin{array}{l}\text { Halamoda } \\
\text { Kenzaoui et } \text { al }^{96}\end{array}$ \\
\hline & PBCA NPs & 146 nm & Human BMEC & Cellular uptake and localization & Weiss et $\mathrm{al}^{95}$ \\
\hline & Silica NPs & $\begin{array}{l}30 \mathrm{~nm} \\
100 \mathrm{~nm} \\
400 \mathrm{~nm}\end{array}$ & $\begin{array}{l}\text { Rat BMEC + } \\
\text { pericytes }\end{array}$ & $\begin{array}{l}\text { Effects of NPs with different sizes } \\
\text { and surface modifications on brain } \\
\text { permeability }\end{array}$ & Hanada et al ${ }^{97}$ \\
\hline & Nano- $\mathrm{TiO}_{2}$ & $25.2 \mathrm{~nm}$ & $\begin{array}{l}\text { Rat BECs + glial } \\
\text { cells }\end{array}$ & $\begin{array}{l}\text { Effects on the integrity of the BBB } \\
\text { and NP-induced inflammatory } \\
\text { responses of BECs }\end{array}$ & Brun et $\mathrm{al}^{98}$ \\
\hline & Magnetic NPs & $60 \mathrm{~nm}$ & $\begin{array}{l}\text { Human BMVEC } \\
+\mathrm{AM}\end{array}$ & $\begin{array}{l}\text { Nanocarriers for targeting BDNF } \\
\text { across the BBB }\end{array}$ & $\begin{array}{l}\text { Pilakka-Kanthikeel } \\
\text { et al }{ }^{100}\end{array}$ \\
\hline & $\begin{array}{l}\text { Glucose-coated gold } \\
\text { NPs }\end{array}$ & $2 \mathrm{~nm}$ core & $\begin{array}{l}\text { Peripheral } \\
\text { vascular } \\
\text { endothelial } \\
\text { cells + AM }\end{array}$ & $\begin{array}{l}\text { Transfer rate of NPs across } \\
\text { the BBB }\end{array}$ & $\begin{array}{l}\text { Gromnicova } \\
\text { et al }\end{array}$ \\
\hline \multirow[t]{4}{*}{ Neuroglial cells } & Nano-ZnO & $45 \mathrm{~nm}$ & Rat astrocytes & $\begin{array}{l}\text { Signaling pathways involved in } \\
\text { NP-induced apoptosis in primary } \\
\text { astrocytes }\end{array}$ & Wang et al ${ }^{107}$ \\
\hline & Nano- $\mathrm{TiO}_{2}$ & $<25 \mathrm{~nm}$ & $\begin{array}{l}\text { Human } \\
\text { astrocytoma } \\
\text { U87 cells }\end{array}$ & Cytotoxicity of NPs & Lai et al ${ }^{109}$ \\
\hline & Si NPs & $150-200 \mathrm{~nm}$ & $\begin{array}{l}\text { Rat microglia } \\
\text { cells }\end{array}$ & Alterations of microglia functions & Choi et $\mathrm{al}^{77}$ \\
\hline & Nano- $\mathrm{TiO}_{2}$ & $<50 \mathrm{~nm}$ & $\begin{array}{l}\text { Human glial cell } \\
\text { U373 and rat } \\
\text { glial cell C6 }\end{array}$ & $\begin{array}{l}\text { NP-induced oxidative stress and } \\
\text { mitochondrial damage in glial cells }\end{array}$ & $\begin{array}{l}\text { Huerta-García } \\
\text { et al'II }\end{array}$ \\
\hline \multirow[t]{4}{*}{ Neurons } & Nano- $\mathrm{TiO}_{2}$ & $21 \mathrm{~nm}$ & Rat PCI 2 cells & $\begin{array}{l}\text { NP-induced oxidative stress and } \\
\text { apoptosis in neurons }\end{array}$ & Liu et $\mathrm{al}^{114}$ \\
\hline & Nano- $\mathrm{TiO}_{2}$ & $25 \mathrm{~nm}$ & SHSY5Y cells & $\begin{array}{l}\text { Cytotoxic and genotoxic effects } \\
\text { of NPs on neuronal cells }\end{array}$ & Valdiglesias et $\mathrm{al}^{115}$ \\
\hline & Nano-ZnO & $30-50 \mathrm{~nm}$ & $\begin{array}{l}\text { Rat primary } \\
\text { neuronal cells }\end{array}$ & $\begin{array}{l}\text { NP-induced cytotoxicity and DNA } \\
\text { damage in neurons }\end{array}$ & Chiang et $\mathrm{al}^{1 / 8}$ \\
\hline & Nano-Ag & $50-100 \mathrm{~nm}$ & $\begin{array}{l}\text { Hippocampal } \\
\text { CAI neurons }\end{array}$ & $\begin{array}{l}\text { Alterations of the action potential } \\
\text { of neurons }\end{array}$ & Liu et $\mathrm{al}^{|2|}$ \\
\hline
\end{tabular}

Abbreviations: BBB, blood-brain barrier; hCMEC/D3, human cerebral microvascular endothelial cell line; NPs, nanoparticles; HCECs, human cerebral endothelial cells; PBCA, poly(n-butylcyanoacrylate); BMEC/BMVEC, brain microvascular endothelial cells; BECs, brain endothelial cells; AM, human astrocytes; BDNF, brain-derived neurotrophic factor; U373, human astrocytoma cell line grade III; C6, rat brain glial tumor cell line; PCI 2 cells, rat pheochromocytoma cells; SHSY5Y cells, human neuroblastoma SHSY5Y cell line. 
of resources and pathological models. ${ }^{97,98}$ In addition to vascular endothelial cells, astrocytes play a key role in the induction and maintenance of the integrity of the BBB. ${ }^{99}$ Thus, the two types of coculture models that have been widely utilized are as follows ${ }^{100,101}$ : (1) brain microvascular endothelial cells + astrocytes and (2) peripheral vascular endothelial cells + astrocytes. Other studies have also utilized "endothelial cells + microglia"102 and "endothelial cells + pericytes" cocultured systems. ${ }^{97}$ At present, cell-based BBB models are the most extensively used because they are easy to obtain and maintain and they are highly effective for the screening studies of drugs and nanocarrier systems. In a recent review by Wong et $\mathrm{al}^{103}$ the authors summarized different types of BBB models, including isolated brain capillaries, cellbased/free models, and dynamic in vitro models (Figure 4). Despite these attempts to mimic in vivo conditions, each of the in vitro BBB models possesses their own advantages and disadvantages, and none of them are completely ideal. More effective in vitro BBB models must be developed for the evaluation of the deliveries of therapeutic agents in further investigations.

Different in vitro studies have focused on evaluating various aspects, such as pharmacology, transport, migration, and the metabolic activity of the BBB. Research has also been focused on DNA damage, the morphological and functional changes of the mitochondria, endoplasmic reticulum, lysosomes, and other organelles, and the transportation mode of internalization, transcytosis and exocytosis. NPs have been demonstrated to be taken up by mammalian cells by such mechanisms as pinocytosis, endocytosis dependent on caveolae and lipid raft composition, and phagocytosis. ${ }^{104}$ The intracellular sites of the localization of NPs vary depending on the cell type and applied method. NPs have entered the endothelial cell monolayer and have accumulated along the endo-lysosomal pathway, which affected the normal morphology and function of the BBB itself. For example, Brun et $\mathrm{al}^{98}$ observed an accumulation of $\mathrm{TiO}_{2} \mathrm{NPs}$ in the endothelial cells of the brain by using an in vitro cell-based rat BBB model. An intense inflammatory response associated with a modulation of the endothelial cell functioning of the brain was also observed. Therefore, an impaired transport capacity resulting from the dysfunction of the endothelial cells of the BBB might constitute the first step in the neurodegeneration process.

Although numerous studies have considered the effects of nanomaterials to the BBB itself, a distinct lack of knowledge exists with respect to the biological effects of NP accumulation within the $\mathrm{BBB}$ of the neighboring cells in the CNS, particularly over the long term. Wiley et al ${ }^{105}$ observed that transferrin-containing gold NPs reached and accumulated in the brain parenchyma following an intravenous injection in mice through a receptor-mediated transcytosis pathway.

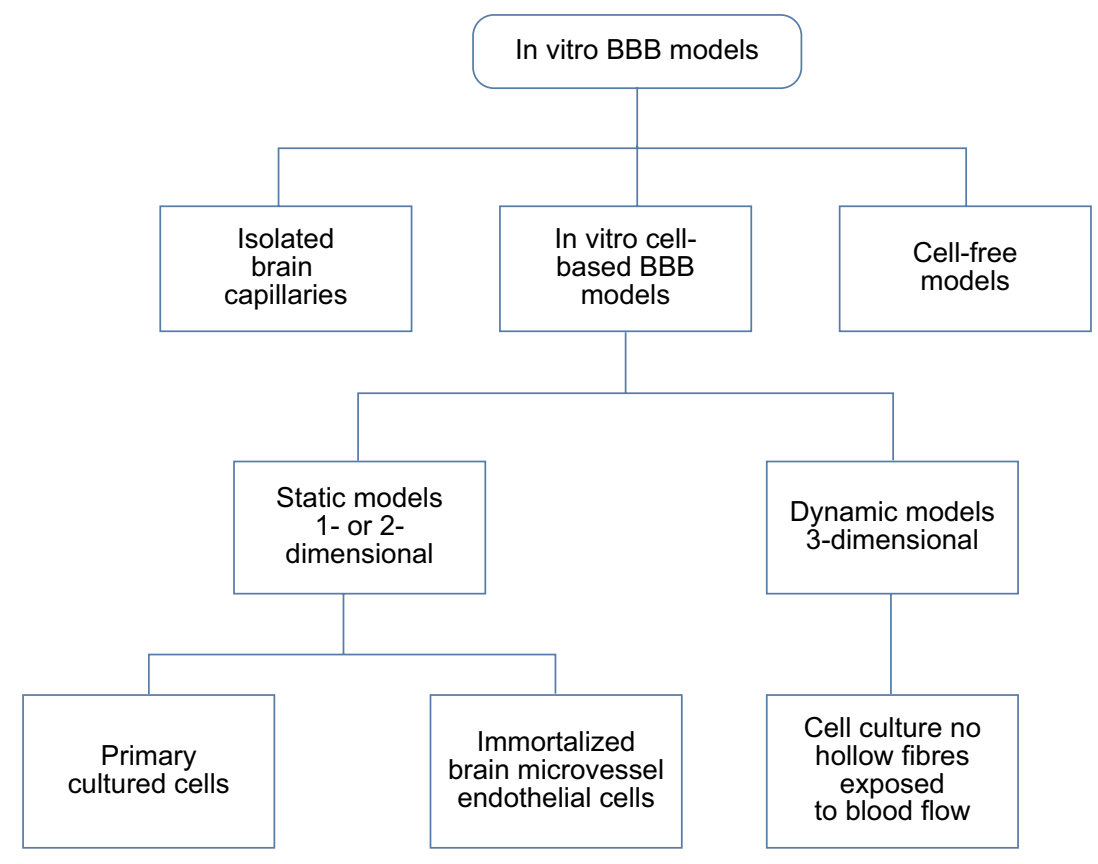

Figure 4 In vitro cell culture models for the studies on drug and NP transport through the BBB.

Note: Reprinted from Adv Drug Deliv Rev, 64(7), Wong HL, Wu XY, Bendayan R. Nanotechnological advances for the delivery of CNS therapeutics. 686-700., Copyright (20/2), with permission from Elsevier. ${ }^{103}$

Abbreviations: NP, nanoparticle; BBB, blood-brain barrier. 
Raghnaill et al ${ }^{106}$ also reported an accumulation over time, but there was no degradation of $100 \mathrm{~nm}$ PS COOH NPs within the lysosomes of the BBB model in vitro. Thus, possible long-term toxicity must be considered, and this toxicity may result from the accumulation of known "toxic" and "nontoxic" NPs.

\section{Neurotoxicity on glial cells or neuroglia}

Among all of the neuroglial cells, astrocytes and microglia have received the most attention. The astrocyte is thought to induce the barrier phenotype of cerebrovascular endothelial cells during development through the release of soluble factors, such as vascular endothelial growth factor. Recently, many studies have attempted to determine the specifics of the NP-astrocyte interactions. For instance, the $\mathrm{ZnO}$ $\mathrm{NP}$-astrocyte interaction was reported to induce an oxidative stress that could trigger cell apoptosis by activating the JNK signaling pathway in cultured primary astrocytes. ${ }^{107}$ A similar finding was observed in the interactions between superparamagnetic iron oxide NPs and astrocytes. ${ }^{108}$ Mixed glial cultures have often been established from the cerebral cortices of neonatal Sprague-Dawley rats and purified astrocytes. Another common cell line is human glial cells (U87 astrocytes). ${ }^{109}$ As the sentinels of the CNS, microglia are the first cells to respond to a disruption of the brain homeostasis and the entry of foreign particles or infectious agents. Once activated, microglia can generate ROS and reactive nitrogen species (RNS) and even elicit an inflammatory response. In most cases, the macrophage cell line was adopted to evaluate its activation and inflammatory reaction. In a neurotoxicity study of Si NPs performed by Choi et $\mathrm{al}^{77}$ even low levels of NPs were capable of increasing ROS and RNS production and inducing cytokine release. These changes had an adverse effect on the microglial function and surrounding neurons. This result was consistent with other toxicity studies that have been conducted more recently. ${ }^{110,111}$

It was also determined that exposure to $\mathrm{Fe}_{2} \mathrm{O}_{3}$ NPs did not cause a significant release of inflammatory factors even though cell phagocytosis and a generation of ROS and NO were observed. ${ }^{112}$ This finding indicated that microglial activation may also act as an alarm and defense system in the processes of the exogenous NPs invading and accumulating in the brain.

\section{Neurotoxicity on neurons}

Neuronal cell lines commonly used for in vitro studies include the following: 1) rat PC12 neuronal cells, ${ }^{113,114}$ which have been derived from a pheochromocytoma of the rat adrenal medulla; PC12 cell lines are commonly used for the neurobiological and neurochemical assessment of NP-induced neurotoxicity; and 2) a human SHSY5Y neuroblastoma cell line, ${ }^{115,116}$ which is perceived as an appropriate cell model for the assessment of neurotoxicity because it possesses many biochemical and functional properties of neurons. ${ }^{117}$ Additionally, primary culture cell lines have also been used in the evaluation of the neurotoxicity of NPs; these lines include human cortical neuronal cells (HCN-1A), rat dopaminergic neurons (N27), rat primary neuronal cells, ${ }^{118}$ embryonic rat striatum or cerebellar granule cells, ${ }^{119}$ and hippocampal CA1 and CA3 neurons. ${ }^{120,121}$

It has now been confirmed that some nanomaterials can exploit the endocytotic pathways both to cross the BBB endothelium in vivo and to enter the neurons or glial cells in vitro. ${ }^{122}$ For instance, Vilella et al ${ }^{66}$ discovered that there was an uptake of NPs in hippocampal neurons that were prepared from rats at embryonic day 18 or 19 . Aside from intracellular accumulation, there was also evidence that different metal oxide NPs affect the membrane potentials of neurons and increase the neuronal firing rate by changing the responses of the potassium channels. ${ }^{90}$ This finding was consistent with a toxicity study of nano-CuO on CA1 hippocampal neurons performed by Xu et al. ${ }^{123}$ Furthermore, this toxic effect may have a physiological impact on animal behavior, which was demonstrated in rats by testing their spatial cognition capabilities. ${ }^{81}$ Recently, the impact of nanomaterials on the CNS, particularly the hippocampal neuronal cells, has been illustrated in a comprehensive review by Yang et al. ${ }^{124}$

\section{Studies on cell-to-cell communication}

The CNS is composed of a dense network of neurons and glial cells that are highly interconnected. Therefore, cell-tocell communication is an important factor in maintaining a functional organization. In recent years, tunneling nanotubes (TNTs) were reported as a new principle of cell-to-cell communication. As a form of membrane continuity, TNTs may be efficient communication tunnels that facilitate information and material exchange. Such communication may even occur over a relatively long distance. ${ }^{125}$ Considering that NPs can be transported intra- and intercellularly within vesicles after internalization by the vesicle, this cell-to-cell transport may be mediated by TNT-like structures in glial and neuronal cells in vitro. Furthermore, the transport was dependent on F-actin and was increased by the induction of TNT-like structures. ${ }^{126}$ Nevertheless, the influence of nanomaterials on cell-to-cell communication in the CNS remains unclear; thus, more in-depth studies are warranted. 


\section{Other problems and future research prospects}

Alongside the rapid advances in the development of nanotechnology-based materials, it has become imperative to elucidate the toxicity of NPs. However, the safety evaluation systems of nanomaterials lag far behind their emerging development and applications. Although researchers have obtained some important information, the risks of NP exposure are not understood sufficiently well to enable the development of a science-based risk assessment. Because investigation into the possible harmful effects of NPs has only been conducted for a few years, it is not surprising that many studies suffer from shortcomings. Therefore, better testing and evaluation systems are urgently needed.

\section{Limitations of the testing methods}

Cytotoxicity in vitro is typically estimated with colorimetric tests. ${ }^{127}$ However, Monteiro-Riviere et al ${ }^{128}$ determined that MTT and neutral red assays, two classical dye-based assays, may produce invalid results in the testing of cell viability when applied with nanomaterials due to their interactions and/or adsorption of the dye/dye products. Furthermore, carbon nanomaterials can interact with assay markers to cause variable results in classical toxicological studies. This finding is consistent with the results of Griffiths et al. ${ }^{129}$ For these reasons, such interactions in cytotoxicity assays must be considered. Another challenge of the testing methods lies in the accurate detection of nanomaterials in biological objects. At present, flow cytometry, induced coupled plasma mass spectroscopy, confocal microscopy, the radioactive tracer technique, and transmission electron microscopy in combination with energy-dispersive X-ray spectroscopy are commonly used to study the cellular uptake of NPs. ${ }^{130,131}$ However, there is not a single method that is satisfactory in obtaining precise information for all types of nanomaterials. Therefore, a combination of the utilization of different testing methods is suggested to provide more accurate results. Furthermore, different assays should be employed according to the certain types of NPs, as well as in addition to imaging techniques. ${ }^{132}$

\section{Limitations of the experimental models}

Under in vivo conditions, nanomaterials could yield different effects compared with in vitro experiments. ${ }^{133}$ Although the observations from in vivo studies are more representative of the situations in living organisms, in some cases, these studies may provide inaccurate results. The challenges are largely related to the experimental models (animals), which are difficult to control and could be affected by various unpredictable factors. Additionally, other considerations, such as dosimetry, the optimization of the dispersion of NPs, the evaluation of the interactions between the nanomaterials and cells, and their biodistributions, create more challenges for in vivo toxicity assessments. ${ }^{134}$

Compared with animal studies, in vitro studies are less expensive, ethically ambiguous, and most importantly, easier to control and reproduce. The first step toward understanding how NPs will react in the body often involves cell culture studies. An increasing number of in vitro cytotoxicity studies of different nanomaterials using various cell lines, incubation times, and colorimetric assays have been published. However, many problems still exist in the studies performed under in vitro conditions. First, the appropriate selections of a set of sensitive cell lines and in vitro assays measuring the different cytotoxicity endpoints are essential to ensure the accurate identification of nanomaterial cytotoxicity. ${ }^{135}$ However, for a certain NP, the selection of the most appropriate cell line is still difficult. To some extent, more sensitive cell models are required to determine the cytotoxicity of a certain type of NP. One example is with the use of nano-ZnO. The majority of the toxicity studies specific to ZnO NPs have relied on the use of immortalized cell lines, which display altered sensitivities to foreign materials/chemicals due to their changes in metabolic processes and significant genetic instabilities. Nevertheless, the toxicity of $\mathrm{ZnO}$ NPs on normal primary human cells and their potential immunomodulatory effects are often neglected. Furthermore, the cytotoxic response varies with different types of cell lines and nanomaterials, making it difficult to develop predictive models because of the lack of detailed and systematic investigations. ${ }^{136}$ Finally, the toxic effects of NPs on rat cell lines (a common in vitro model) may not be able to accurately reflect the effects in humans.

In vitro investigations will not be able to completely determine the in vivo situations until further in vivo analyses have been performed to confirm their findings. ${ }^{133}$ In a recent review by Donaldson et $\mathrm{a}^{137}$ the authors stated that cells in culture did not experience the range of pathogenic changes that might occur under in vivo conditions, which were partially related to the issues of translocation, toxicokinetics, and coordinated tissue responses. Some other studies have also cast doubt on the results obtained from in vitro models, especially in models in submersed conditions when NPs were suspended in media that could impact the dispersion and dissolution. ${ }^{15,138}$

The major challenges of the assessment of neurotoxicity of NPs are summarized in Figure 5. 


\section{Possible future research prospects}

Until now, the understanding of nanomaterial neurotoxicology has been extremely limited. In-depth studies are warranted, particularly when considering the recent emphasis on the use of nanocarriers for drug delivery in the brain. ${ }^{139}$ Here, we have provided some suggestions on the research prospects that require further detailed investigations.

As indicated by Laurent et al the effects of the protein corona on NP-cell interactions are often ignored at the nano-bio interface. ${ }^{140}$ Because in vitro biological studies typically use low amounts ( $10 \%$ dilution or less, depending on cell types) of animal-derived serum, which is present in in vivo studies, NP coronas are likely to form at different protein-to-NP ratios between the in vitro and in vivo studies. ${ }^{141}$ In this sense, in vitro models that evaluate the NPs for brain-related diseases are supposed to use the corona-coated NPs to reflect the real in vivo situations, ${ }^{142}$ as the protein corona may cover the designed functional groups and significantly reduce the ability of NPs to cross through the cell barriers. ${ }^{143,144}$ Another consideration with respect to the protein corona arises from the evaluation of its structural evolution over time. NPs will interact with tissues and cells in living organisms, including passing through cellular membranes and being transported to the final subcellular locations. Therefore, the detailed changes of the nanomaterial corona at these stages and their implications require further study. Additionally, as described in the limitations of the in vitro models, more appropriate cell lines should be developed. Takhar and Mahant ${ }^{145}$ recently suggested the possibility of using transgenic cell lines carrying human genes, which may be more predictive to situations involving humans than the traditional rat cells.

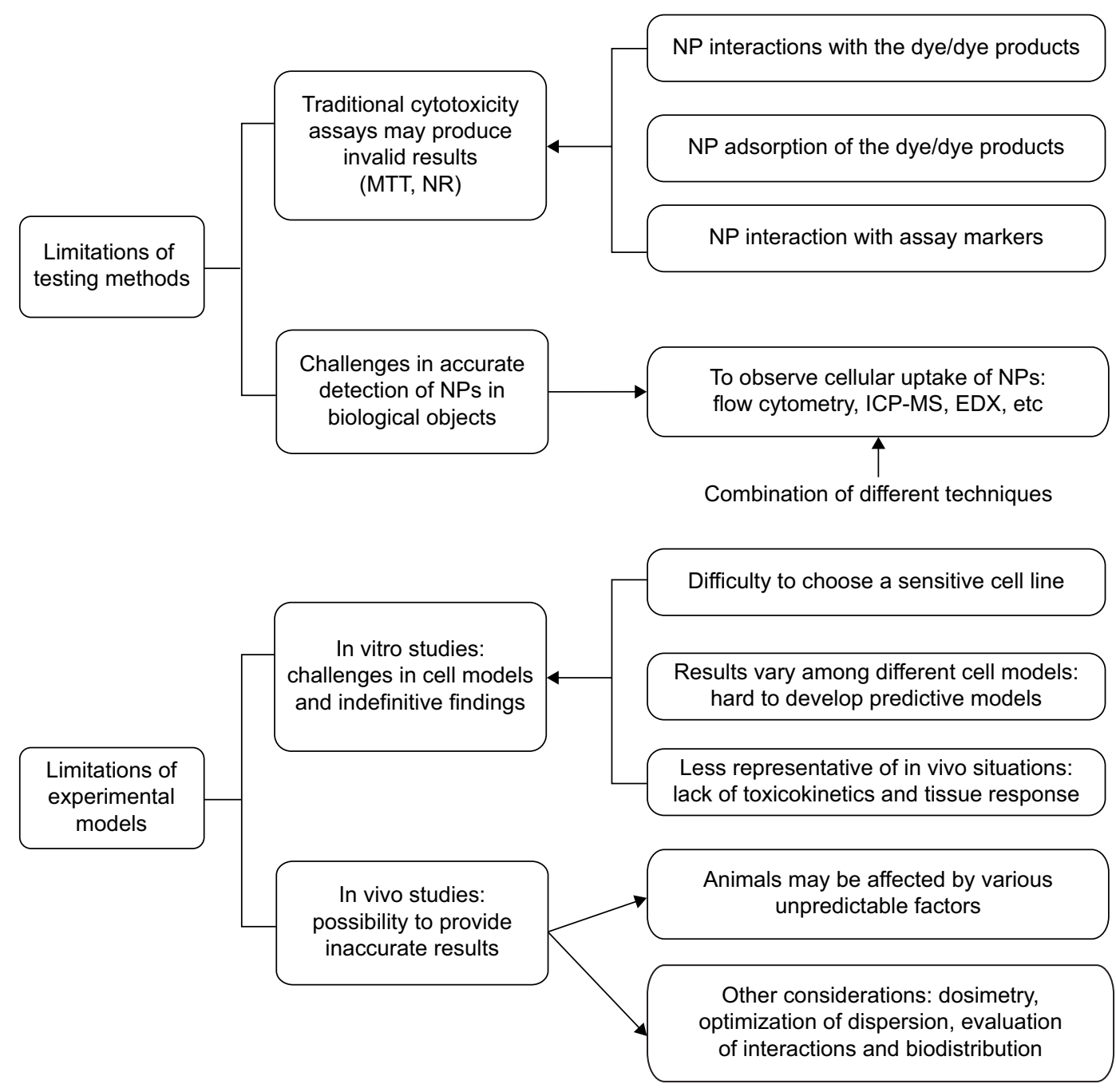

Figure 5 Existing problems in assessing the neurotoxicity of NPs.

Note: This scheme summarizes the major limitations of the testing methods and experimental models.

Abbreviations: NPs, nanoparticles; NR, neutral red; ICP-MS, induced coupled plasma mass spectroscopy; EDX, energy-dispersive X-ray spectroscopy; MTT, 3-(4,5Dimethylthiazol-2-yl)-2,5-diphenyltetrazolium bromide. 
With regard to animal studies, the effects of the life stages should be considered. First, fetal life and early childhood are vulnerable periods. These life stages are of great importance for the rapid growth of whole organism, cell differentiation, and organogenesis, and in the case of the brain, are involved in critical processes in neurodevelopment. If toxic exposures occur at these stages, they could alter the trajectory of the development of the brain, which may have minor effects in the early years and profound implications later in life. ${ }^{146} \mathrm{Cur}-$ rently, growing evidence from animal research has confirmed that the CNS is highly vulnerable to chemical injury during development. ${ }^{147}$ Therefore, particular attention should be given to determine the influence of nanomaterial exposure at these developmental stages.

Aging may also represent an important factor in the susceptibility of NP-induced neurotoxicity. Aged brains have demonstrated an increase in cytokine and microglial activation and are more vulnerable to environmental insults, particularly in pro-inflammatory stimuli, ${ }^{148,149}$ including various NPs. In recent years, it has been predicted that many neurodegenerative diseases can result from the cumulative exposure throughout a lifetime. ${ }^{150}$ This finding was consistent with the observations in another toxicity research conducted by Qin et al. ${ }^{151}$ In this animal study, chronic neuroinflammation in response to a single intraperitoneal injection of lipopolysaccharide, a potent inflammatory stimulus, in young adult mice only culminated in dopaminergic neurotoxicity in aged animals. Other associated factors, such as the sex and genetic background, should also be investigated. ${ }^{152,153}$ Recently, it was reported that the differential expression of the enzyme paraoxonase 2 (PON2) between male and female brains may be responsible for a number of sex differences with regard to neurotoxicity. ${ }^{152}$ Gene-nanomaterial interactions also played an important role in NP-induced neurotoxicity, as genetic polymorphisms may modulate individual susceptibilities to nanomaterials. Given the prominent role of oxidative stress, genetically based differences in antioxidant enzymes may predispose certain individuals to significant air pollution neurotoxicities. ${ }^{153}$

A continuous exposure may result in the significant accumulation of NPs in a secondary target organ. Therefore, it is important to obtain data on the retention characteristics of NPs in both primary and secondary target organs, as well as NP elimination pathways. No data on NP elimination in the CNS are available yet. It is conceivable that the CSF, via its connections to the nasal lymphatic system and to the circulation of blood, could be an excretory pathway for the brain, and this topic should be investigated in future studies. Indeed, from his review on CSF barriers, Segal ${ }^{154}$ concluded that the CSF may act as not only a compartment for the distribution of substances to different brain regions but also an elimination route for waste products into the blood circulation because the brain has no lymphatics. However, this is a single study and need to be complemented by more systematic research on nanomaterial elimination.

\section{Summary}

Nanomaterials have made major contributions to modern dentistry in various areas, including composite resin and bonding systems, coating materials for dental implants, and dental restorations. The wide applications of these dental nanomaterials have created more exposure opportunities to these NPs in both dental staff and patients. Because the CNS may be a potential target organ of nanomaterials, it is essential to determine the neurotoxic effects of NPs. Although the impact of NPs on the CNS has received considerable attention in recent years, the data and findings obtained from the in vivo and in vitro studies are still limited. The limitations of the present testing methods and the experimental models also make it difficult to establish a science-based evaluation system. Better testing and evaluation systems are urgently needed. In conclusion, more efforts are required to ensure the safe use of nanomaterials.

\section{Acknowledgments}

This work was supported by the National Natural Science Foundation of China (31070857, 50973045, 51172283, 81400557), and the Project on the Integration of Industry, Education and Research of Guangdong Province, People's Republic of China (2012B091000147).

\section{Disclosure}

The authors declare no conflicts of interest in relation to this paper.

\section{References}

1. Bleeker EA, de Jong WH, Geertsma RE, et al. Considerations on the EU definition of a nanomaterial: science to support policy making. Regul Toxicol Pharm. 2013;65(1):119-125.

2. Juanola-Feliu E. The nanotechnology revolution in Barcelona: innovation and creativity by universities. Manage Int. 2009;13:111-123.

3. Kasraei S, Sami L, Hendi S, Alikhani MY, Rezaei-Soufi L, Khamverdi Z. Antibacterial properties of composite resins incorporating silver and zinc oxide nanoparticles on Streptococcus mutans and Lactobacillus. Restor Dent Endod. 2014;39(2):109-114.

4. Niu LN, Fang M, Jiao K, et al. Tetrapod-like zinc oxide whisker enhancement of resin composite. J Dent Res. 2010;89(7):746-750.

5. Memarzadeh K, Sharili AS, Huang J, Rawlinson SC, Allaker RP. Nanoparticulate zinc oxide as a coating material for orthopedic and dental implants. J Biomed Mater Res A. 2015;103(3):981-989. 
6. Javidi M, Zarei M, Naghavi N, Mortazavi M, Nejat AH. Zinc oxide nano-particles as sealer in endodontics and its sealing ability. Contemp Clin Dent. 2014;5(1):20-24.

7. Frohlich E, Roblegg E. Models for oral uptake of nanoparticles in consumer products. Toxicology. 2012;291(1-3):10-17.

8. Keelan JA. Nanotoxicology: nanoparticles versus the placenta. Nat Nanotechnol. 2011;6(5):263-264.

9. Shimizu M, Tainaka H, Oba T, Mizuo K, Umezawa M, Takeda K. Maternal exposure to nanoparticulate titanium dioxide during the prenatal period alters gene expression related to brain development in the mouse. Part Fibre Toxicol. 2009;6:20.

10. Lu S, Duffin R, Poland C, et al. Efficacy of simple short-term in vitro assays for predicting the potential of metal oxide nanoparticles to cause pulmonary inflammation. Environ Health Perspect. 2009;117(2): 241-247.

11. Lee CM, Jeong HJ, Yun KN, et al. Optical imaging to trace near infrared fluorescent zinc oxide nanoparticles following oral exposure. Int $J$ Nanomedicine. 2012;7:3203-3209.

12. Wang Y, Chen Z, Ba T, et al. Susceptibility of young and adult rats to the oral toxicity of titanium dioxide nanoparticles. Small. 2013;9(9-10): $1742-1752$.

13. Stern ST, McNeil SE. Nanotechnology safety concerns revisited. Toxicol Sci. 2008;101(1):4-21.

14. Medina C, Santos-MartinezMJ, Radomski A, Corrigan OI, Radomski MW. Nanoparticles: pharmacological and toxicological significance. $\mathrm{Br} J$ Pharmacol. 2007;150(5):552-558.

15. Adamcakova-Dodd A, Stebounova LV, Kim JS, et al. Toxicity assessment of zinc oxide nanoparticles using sub-acute and sub-chronic murine inhalation models. Part Fibre Toxicol. 2014;11:15.

16. Ma L, Liu J, Li N, et al. Oxidative stress in the brain of mice caused by translocated nanoparticulate $\mathrm{TiO}_{2}$ delivered to the abdominal cavity. Biomaterials. 2010;31(1):99-105.

17. Nel A, Xia T, Madler L, Li N. Toxic potential of materials at the nanolevel. Science. 2006;311(5761):622-627.

18. Balos S, Pilic B, Petronijevic B, Markovic D, Mirkovic S, Sarcev I. Improving mechanical properties of flowable dental composite resin by adding silica nanoparticles. Vojnosanit Pregl. 2013;70(5): 477-483.

19. Wang R, Bao S, Liu F, et al. Wear behavior of light-cured resin composites with bimodal silica nanostructures as fillers. Mat Sci Eng C Mater. 2013;33(8):4759-4766.

20. $\mathrm{Xu} \mathrm{HH}$, Weir MD, Sun $\mathrm{L}$, et al. Strong nanocomposites with $\mathrm{Ca}$, PO(4), and F release for caries inhibition. J Dent Res. 2010;89(1): $19-28$.

21. Xia Y, Zhang F, Xie H, Gu N. Nanoparticle-reinforced resin-based dental composites. J Dent. 2008;36(6):450-455.

22. Wang W, Sun X, Huang L, et al. Structure-property relationships in hybrid dental nanocomposite resins containing monofunctional and multifunctional polyhedral oligomeric silsesquioxanes. Int $J$ Nanomedicine. 2014;9:841-852.

23. Melo MA, Cheng L, Zhang K, Weir MD, Rodrigues LK, Xu HH. Novel dental adhesives containing nanoparticles of silver and amorphous calcium phosphate. J Biomed Mater Res B Appl Biomater. 2013;29(2):199-210.

24. Wagner A, Belli R, Stotzel C, Hilpert A, Muller FA, Lohbauer U. Biomimetically- and hydrothermally-grown HAp nanoparticles as reinforcing fillers for dental adhesives. J Adhes Dent. 2013;15(5):413-422.

25. Habekost LV, Camacho GB, Lima GS, Ogliari FA, Cubas GB, Moraes RR. Nanoparticle loading level and properties of experimental hybrid resin luting agents. J Prosthodont. 2012;21(7):540-545.

26. Jallot E, Nedelec JM, Grimault AS, et al. STEM and EDXS characterisation of physico-chemical reactions at the periphery of sol-gel derived Zn-substituted hydroxyapatites during interactions with biological fluids. Colloid Surf B. 2005;42(3-4):205-210.

27. Krisanapiboon A, Buranapanitkit B, Oungbho K. Biocompatability of hydroxyapatite composite as a local drug delivery system. J Orthop Surg (Hong Kong). 2006;14(3):315-318.
28. Qi X, Li H, Qiao B, et al. Development and characterization of an injectable cement of nano calcium-deficient hydroxyapatite/multi(amino acid) copolymer/calcium sulfate hemihydrate for bone repair. Int $J$ Nanomedicine. 2013;8:4441-4452.

29. Huber FX, Belyaev O, Hillmeier J, et al. First histological observations on the incorporation of a novel nanocrystalline hydroxyapatite paste OSTIM in human cancellous bone. BMC Musculoskelet Disord. 2006;7:50.

30. Yang C, Lee JS, Jung UW, Seo YK, Park JK, Choi SH. Periodontal regeneration with nano-hyroxyapatite-coated silk scaffolds in dogs. J Periodontal Implant Sci. 2013;43(6):315-322.

31. An SH, Matsumoto T, Miyajima H, Nakahira A, Kim KH, Imazato S. Porous zirconia/hydroxyapatite scaffolds for bone reconstruction. Dent Mater. 2012;28(12):1221-1231.

32. De Aza AH, Chevalier J, Fantozzi G, Schehl M, Torrecillas R. Crack growth resistance of alumina, zirconia and zirconia toughened alumina ceramics for joint prostheses. Biomaterials. 2002;23(3):937-945.

33. Uno M, Kurachi M, Wakamatsu N, Doi Y. Effects of adding silver nanoparticles on the toughening of dental porcelain. J Prosthet Dent. 2013;109(4):241-247.

34. Han Y, Kiat-amnuay S, Powers JM, Zhao Y. Effect of nano-oxide concentration on the mechanical properties of a maxillofacial silicone elastomer. J Prosthet Dent. 2008;100(6):465-473.

35. Acosta-Torres LS, Mendieta I, Nunez-Anita RE, Cajero-Juarez M, Castano VM. Cytocompatible antifungal acrylic resin containing silver nanoparticles for dentures. Int J Nanomedicine. 2012;7:4777-4786.

36. Karlsson M, Palsgard E, Wilshaw PR, Di Silvio L. Initial in vitro interaction of osteoblasts with nano-porous alumina. Biomaterials. 2003;24(18):3039-3046.

37. Pardun K, Treccani L, Volkmann E, et al. Characterization of wet powder-sprayed zirconia/calcium phosphate coating for dental implants. Clin Implant Dent Relat Res. 2015;17(1):186-198.

38. Uezono M, Takakuda K, Kikuchi M, Suzuki S, Moriyama K. Hydroxyapatite/collagen nanocomposite-coated titanium rod for achieving rapid osseointegration onto bone surface. J Biomed Mater Res B Appl Biomater. 2013;101(6):1031-1038.

39. Mendonca G, Mendonca DB, Aragao FJ, Cooper LF. Advancing dental implant surface technology - from micron- to nanotopography. Biomaterials. 2008;29(28):3822-3835.

40. Lebold T, Jung C, Michaelis J, Brauchle C. Nanostructured silica materials as drug-delivery systems for doxorubicin: single molecule and cellular studies. Nano Lett. 2009;9(8):2877-2883.

41. Mu L, Feng SS. A novel controlled release formulation for the anticancer drug paclitaxel (Taxol): PLGA nanoparticles containing vitamin E TPGS. J Control Release. 2003;86(1):33-48.

42. Melancon MP, Lu W, Zhong M, et al. Targeted multifunctional goldbased nanoshells for magnetic resonance-guided laser ablation of head and neck cancer. Biomaterials. 2011;32(30):7600-7608.

43. Erdogan S. Liposomal nanocarriers for tumor imaging. $J$ Biomed Nanotechnol. 2009;5(2):141-150.

44. Weir A, Westerhoff P, Fabricius L, Hristovski K, von Goetz N. Titanium dioxide nanoparticles in food and personal care products. Environ Sci Technol. 2012;46(4):2242-2250.

45. Geraets L, Oomen AG, Schroeter JD, Coleman VA, Cassee FR. Tissue distribution of inhaled micro- and nano-sized cerium oxide particles in rats: results from a 28-day exposure study. Toxicol Sci. 2012;127(2):463-473.

46. Chen Y, Liu L. Modern methods for delivery of drugs across the bloodbrain barrier. Adv Drug Deliv Rev. 2012;64(7):640-665.

47. Patel T, Zhou J, Piepmeier JM, Saltzman WM. Polymeric nanoparticles for drug delivery to the central nervous system. Adv Drug Deliv Rev. 2012;64(7):701-705.

48. Beduneau A, Saulnier P, Benoit JP. Active targeting of brain tumors using nanocarriers. Biomaterials. 2007;28(33):4947-4967.

49. Spector R. Nature and consequences of mammalian brain and CSF efflux transporters: four decades of progress. J Neurochem. 2010;112(1): $13-23$. 
50. Kao YY, Cheng TJ, Yang DM, Wang CT, Chiung YM, Liu PS. Demonstration of an olfactory bulb-brain translocation pathway for $\mathrm{ZnO}$ nanoparticles in rodent cells in vitro and in vivo. $J$ Mol Neurosci. 2012;48(2):464-471.

51. Hwang SR, Kim K. Nano-enabled delivery systems across the bloodbrain barrier. Arch Pharm Res. 2014;37(1):24-30.

52. Caraglia M, De Rosa G, Salzano G, et al. Nanotech revolution for the anti-cancer drug delivery through blood-brain-barrier. Curr Cancer Drug Tar. 2012;12(3):186-196.

53. Barbu E, Molnar E, Tsibouklis J, Gorecki DC. The potential for nanoparticle-based drug delivery to the brain: overcoming the bloodbrain barrier. Expert Opin Drug Deliv. 2009;6(6):553-565.

54. Jain KK. Nanobiotechnology-based strategies for crossing the bloodbrain barrier. Nanomedicine (Lond). 2012;7(8):1225-1233.

55. Watson RE, Desesso JM, Hurtt ME, Cappon GD. Postnatal growth and morphological development of the brain: a species comparison. Birth Defects Res B Dev Reprod Toxicol. 2006;77(5):471-484.

56. Yamashita K, Yoshioka Y, Higashisaka K, et al. Silica and titanium dioxide nanoparticles cause pregnancy complications in mice. Nat Nanotechnol. 2011;6(5):321-328.

57. Okada Y, Tachibana K, Yanagita S, Takeda K. Prenatal exposure to zinc oxide particles alters monoaminergic neurotransmitter levels in the brain of mouse offspring. J Toxicol Sci. 2013;38(3):363-370.

58. Yu LE, Yung LYL, Ong CN, et al. Translocation and effects of gold nanoparticles after inhalation exposure in rats. Nanotoxicology. 2007;1(3):235-242.

59. Biddlestone-Thorpe L, Marchi N, Guo K, et al. Nanomaterial-mediated CNS delivery of diagnostic and therapeutic agents. Adv Drug Deliv Rev 2012;64(7):605-613.

60. Wang B, Feng WY, Zhu MT, et al. Neurotoxicity of low-dose repeatedly intranasal instillation of nano- and submicron-sized ferric oxide particles in mice. J Nanopart Res. 2009;11(1):41-53.

61. Shah L, Yadav S, Amiji M. Nanotechnology for CNS delivery of biotherapeutic agents. Drug Deliv Transl Res. 2013;3(4):336-351.

62. De Lorenzo AJ. The olfactory neuron and the blood-brain barrier. London: CIBA Foundation Symposium Series J\&A Churchill; 1970.

63. Thorne RG, Pronk GJ, Padmanabhan V, Frey WH 2nd. Delivery of insulin-like growth factor-I to the rat brain and spinal cord along olfactory and trigeminal pathways following intranasal administration Neuroscience. 2004;127(2):481-496.

64. Dhuria SV, Hanson LR, Frey WH 2nd. Intranasal delivery to the central nervous system: mechanisms and experimental considerations. JPharm Sci. 2010;99(4):1654-1673.

65. Oberdorster G, Oberdorster E, Oberdorster J. Nanotoxicology: an emerging discipline evolving from studies of ultrafine particles. Environ Health Perspect. 2005;113(7):823-839.

66. Vilella A, Tosi G, Grabrucker AM, et al. Insight on the fate of CNStargeted nanoparticles. Part I: Rab5-dependent cell-specific uptake and distribution. J Control Release. 2014;174:195-201.

67. Amara S, Ben-Slama I, Mrad I, et al. Acute exposure to zinc oxide nanoparticles does not affect the cognitive capacity and neurotransmitters levels in adult rats. Nanotoxicology. 2014;8(suppl 1):208-215.

68. Zhang L, Bai R, Li B, et al. Rutile $\mathrm{TiO}_{2}$ particles exert size and surface coating dependent retention and lesions on the murine brain. Toxicol Lett. 2011;207(1):73-81.

69. Kumar V, Kumari A, Guleria P, Yadav SK. Evaluating the toxicity of selected types of nanochemicals. Rev Environ Contam T. 2012;215: 39-121.

70. Li Y, Li J, Yin J, et al. Systematic influence induced by $3 \mathrm{~nm}$ titanium dioxide following intratracheal instillation of mice. $J$ Nanosci Nanotechno. 2010;10(12):8544-8549.

71. Ze Y, Hu R, Wang X, et al. Neurotoxicity and gene-expressed profile in brain-injured mice caused by exposure to titanium dioxide nanoparticles. J Biomed Mater Res A. 2014;102(2):470-478.

72. Kwon JT, Seo GB, Jo, et al. Aluminum nanoparticles induce ERK and p38MAPK activation in rat brain. Toxicol Res. 2013;29(3): $181-185$.
73. Marano F, Hussain S, Rodrigues-Lima F, Baeza-Squiban A, Boland S. Nanoparticles: molecular targets and cell signalling. Arch Toxicol. 2011;85(7):733-741.

74. Shrivastava R, Raza S, Yadav A, Kushwaha P, Flora SJS. Effects of sub-acute exposure to $\mathrm{TiO}_{2}, \mathrm{ZnO}$ and $\mathrm{Al}_{2} \mathrm{O}_{3}$ nanoparticles on oxidative stress and histological changes in mouse liver and brain. Drug Chem Toxicol. 2014;37(3):336-347.

75. Hu R, Zheng L, Zhang T, et al. Molecular mechanism of hippocampal apoptosis of mice following exposure to titanium dioxide nanoparticles. J Hazard Mater. 2011;191(1-3):32-40.

76. Win-Shwe TT, Fujimaki H. Nanoparticles and neurotoxicity. Int J Mol Sci. 2011;12(9):6267-6280.

77. Choi J, Zheng QD, Katz HE, Guilarte TR. Silica-based nanoparticle uptake and cellular response by primary microglia. Environ Health Perspect. 2010;118(5):589-595.

78. Tobe EH. Mitochondrial dysfunction, oxidative stress, and major depressive disorder. Neuropsych Dis Treat. 2013;9:567-573.

79. Zhang Y, Yu CG, Huang GY, Wang CL, Wen LP. Nano rare-earth oxides induced size-dependent vacuolization: an independent pathway from autophagy. Int $J$ Nanomedicine. 2010;5:601-609.

80. Chen L, Miao Y, Chen L, et al. The role of low levels of fullerene C60 nanocrystals on enhanced learning and memory of rats through persistent CaMKII activation. Biomaterials. 2014;35(34):9269-9279.

81. Han DD, Tian YT, Zhang T, Ren GG, Yang Z. Nano-zinc oxide damages spatial cognition capability via over-enhanced long-term potentiation in hippocampus of Wistar rats. Int J Nanomedicine. 2011;6:1453-1461.

82. Li T, Shi TT, Li XB, Zeng SL, Yin LH, Pu YP. Effects of Nano- $\mathrm{MnO}_{2}$ on dopaminergic neurons and the spatial learning capability of rats. Int J Env Res Pub He. 2014;11(8):7918-7930.

83. Kim EM, Palmer P, Howard V, et al. Effect of Intracerebroventricular injection of $\mathrm{TiO}_{2}$ nanoparticles on complex behaviour in the rat. J Nanosci Nanotechno. 2013;13(12):8325-8330.

84. Cui Y, Chen X, Zhou Z, et al. Prenatal exposure to nanoparticulate titanium dioxide enhances depressive-like behaviors in adult rats. Chemosphere. 2014;96:99-104.

85. Sorce S, Krause KH. NOX enzymes in the central nervous system: from signaling to disease. Antioxid Redox Sign. 2009;11(10):2481-2504.

86. Massaad CA, Klann E. Reactive oxygen species in the regulation of synaptic plasticity and memory. Antioxid Redox Sign. 2011;14(10): 2013-2054.

87. Schappi MG, Jaquet V, Belli DC, Krause KH. Hyperinflammation in chronic granulomatous disease and anti-inflammatory role of the phagocyte NADPH oxidase. Semin Immunopathol. 2008;30(3):255-271.

88. Thomas MP, Chartrand K, Reynolds A, Vitvitsky V, Banerjee R, Gendelman HE. Ion channel blockade attenuates aggregated alpha synuclein induction of microglial reactive oxygen species: relevance for the pathogenesis of Parkinson's disease. J Neurochem. 2007;100(2): 503-519.

89. Hu R, Gong X, Duan Y, et al. Neurotoxicological effects and the impairment of spatial recognition memory in mice caused by exposure to $\mathrm{TiO}_{2}$ nanoparticles. Biomaterials. 2010;31(31):8043-8050.

90. Krol S. Challenges in drug delivery to the brain: nature is against us. $J$ Control Release. 2012;164(2):145-155.

91. Armulik A, Genové G, Mäe M, et al. Pericytes regulate the blood-brain barrier. Nature. 2010;468(7323):557-U231.

92. Wohlfart S, Gelperina S, Kreuter J. Transport of drugs across the blood-brain barrier by nanoparticles. J Control Release. 2012;161(2):264-273.

93. Powers CM, Bale AS, Kraft AD, et al. Developmental neurotoxicity of engineered nanomaterials: identifying research needs to support human health risk assessment. Toxicol Sci. 2013;134(2):225-242.

94. Ye D, Raghnaill MN, Bramini M, et al. Nanoparticle accumulation and transcytosis in brain endothelial cell layers. Nanoscale. 2013;5(22): 11153-11165.

95. Weiss CK, Kohnle MV, Landfester K, et al. The first step into the brain: uptake of NIO-PBCA nanoparticles by endothelial cells in vitro and in vivo, and direct evidence for their blood-brain barrier permeation. Chem Med Chem. 2008;3(9):1395-1403. 
96. Halamoda Kenzaoui B, Chapuis Bernasconi C, Guney-Ayra S, Juillerat-Jeanneret L. Induction of oxidative stress, lysosome activation and autophagy by nanoparticles in human brain-derived endothelial cells. Biochem J. 2012;441(3):813-821.

97. Hanada S, Fujioka K, Inoue Y, Kanaya F, Manome Y, Yamamoto K. Cell-based in vitro blood-brain barrier model can rapidly evaluate nanoparticles' brain permeability in association with particle size and surface modification. Int J Mol Sci. 2014;15(2):1812-1825.

98. Brun E, Carriere M, Mabondzo A. In vitro evidence of dysregulation of blood-brain barrier function after acute and repeated/long-term exposure to $\mathrm{TiO}_{2}$ nanoparticles. Biomaterials. 2012;33(3):886-896.

99. Ogunshola OO. In vitro modeling of the blood-brain barrier: simplicity versus complexity. Curr Pharm Design. 2011;17(26):2755-2761.

100. Pilakka-Kanthikeel S, Atluri VSR, Sagar V, Saxena SK, Nair M. Targeted brain derived neurotropic factors (BDNF) delivery across the blood-brain barrier for neuro-protection using magnetic nano carriers: an in-vitro study. PLoS One. 2013;8(4):e62241.

101. Gromnicova R, Davies HA, Sreekanthreddy P, et al. Glucose-coated gold nanoparticles transfer across human brain endothelium and enter astrocytes in vitro. PLoS One. 2013;8(12):e81043.

102. Sumi N, Nishioku T, Takata F, et al. Lipopolysaccharide-activated microglia induce dysfunction of the blood-brain barrier in rat Microvascular endothelial cells co-cultured with microglia. Cell Mol Neurobiol. 2010;30(2):247-253.

103. Wong HL, Wu XY, Bendayan R. Nanotechnological advances for the delivery of CNS therapeutics. Adv Drug Deliv Rev. 2012;64(7): 686-700.

104. AshaRani PV, Hande MP, Valiyaveettil S. Anti-proliferative activity of silver nanoparticles. BMC Cell Biol. 2009;10:65.

105. Wiley DT, Webster P, Gale A, Davis ME. Transcytosis and brain uptake of transferrin-containing nanoparticles by tuning avidity to transferrin receptor. P Natl Acad Sci US A. 2013;110(21):8662-8667.

106. Raghnaill MN, Bramini M, Ye D, et al. Paracrine signalling of inflammatory cytokines from an in vitro blood brain barrier model upon exposure to polymeric nanoparticles. Analyst. 2014;139(5):923-930.

107. Wang J, Deng X, Zhang F, Chen D, Ding W. ZnO nanoparticle-induced oxidative stress triggers apoptosis by activating JNK signaling pathway in cultured primary astrocytes. Nanoscale Res Lett. 2014;9(1):117.

108. Pickard MR, Jenkins SI, Koller CJ, Furness DN, Chari DM. Magnetic nanoparticle labeling of astrocytes derived for neural transplantation. Tissue Eng Part C Methods. 2011;17(1):89-99.

109. Lai JC, Lai MB, Jandhyam S, et al. Exposure to titanium dioxide and other metallic oxide nanoparticles induces cytotoxicity on human neural cells and fibroblasts. Int J Nanomedicine. 2008;3(4):533-545.

110. Xue Y, Wu J, Sun J. Four types of inorganic nanoparticles stimulate the inflammatory reaction in brain microglia and damage neurons in vitro. Toxicol Lett. 2012;214(2):91-98.

111. Huerta-García E, Pérez-Arizti JA, Márquez-Ramírez SG, et al. Titanium dioxide nanoparticles induce strong oxidative stress and mitochondrial damage in glial cells. Free Radic Biol Med. 2014;73:84-94.

112. Wang Y, Wang B, Zhu MT, et al. Microglial activation, recruitment and phagocytosis as linked phenomena in ferric oxide nanoparticle exposure. Toxicol Lett. 2011;205(1):26-37.

113. Wu J, Sun JA, Xue Y. Involvement of JNK and P53 activation in G2/M cell cycle arrest and apoptosis induced by titanium dioxide nanoparticles in neuron cells. Toxicol Lett. 2010;199(3):269-276.

114. Liu SC, Xu LJ, Zhang T, Ren GG, Yang Z. Oxidative stress and apoptosis induced by nanosized titanium dioxide in PC12 cells. Toxicology. 2010;267(1-3):172-177.

115. Valdiglesias V, Costa C, Kiliç G, et al. Neuronal cytotoxicity and genotoxicity induced by zinc oxide nanoparticles. Environ Int. 2013;55: 92-100.

116. Valdiglesias V, Costa C, Sharma V, et al. Comparative study on effects of two different types of titanium dioxide nanoparticles on human neuronal cells. Food Chem Toxicol. 2013;57:352-361.
117. Xie HR, Hu LS, Li GY. SH-SY5Y human neuroblastoma cell line: in vitro cell model of dopaminergic neurons in Parkinson's disease. Chin Med J (Engl). 2010;123(8):1086-1092.

118. Chiang HM, Xia Q, Zou X, et al. Nanoscale ZnO induces cytotoxicity and DNA damage in human cell lines and rat primary neuronal cells. J Nanosci Nanotechnol. 2012;12(3):2126-2135.

119. Zieminska E, Stafiej A, Struzynska L. The role of the glutamatergic NMDA receptor in nanosilver-evoked neurotoxicity in primary cultures of cerebellar granule cells. Toxicology. 2014;315:38-48.

120. Zhao J, Xu L, Zhang T, Ren G, Yang Z. Influences of nanoparticle zinc oxide on acutely isolated rat hippocampal CA3 pyramidal neurons. Neurotoxicology. 2009;30(2):220-230.

121. Liu Z, Ren G, Zhang T, Yang Z. Action potential changes associated with the inhibitory effects on voltage-gated sodium current of hippocampal CA1 neurons by silver nanoparticles. Toxicology. 2009;264(3):179-184.

122. Grabrucker AM, Garner CC, Boeckers TM, et al. Development of novel $\mathrm{Zn}^{2+}$ loaded nanoparticles designed for cell-type targeted drug release in CNS neurons: in vitro evidences. PLoS One. 2011;6(3): e17851.

123. Xu LJ, Zhao JX, Zhang T, Ren GG, Yang Z. In vitro study on influence of nano particles of $\mathrm{CuO}$ on $\mathrm{CA} 1$ pyramidal neurons of rat hippocampus potassium currents. Environ Toxicol. 2009;24(3):211-217.

124. Yang Z, Liu ZW, Allaker RP, et al. A review of nanoparticle functionality and toxicity on the central nervous system. JR Soc Interface. 2010;7(supp1 4):S411-S422.

125. Wang Y, Cui J, Sun X, Zhang Y. Tunneling-nanotube development in astrocytes depends on p53 activation. Cell Death Differ. 2011;18(4): $732-742$.

126. Tosi G, Vilella A, Chhabra R, et al. Insight on the fate of CNS-targeted nanoparticles. Part II: intercellular neuronal cell-to-cell transport. J Control Release. 2014;177:96-107.

127. Park EJ, Yi J, Kim Y, Choi K, Park K. Silver nanoparticles induce cytotoxicity by a Trojan-horse type mechanism. Toxicol In Vitro. 2010;24(3):872-878.

128. Monteiro-Riviere NA, Inman AO, Zhang LW. Limitations and relative utility of screening assays to assess engineered nanoparticle toxicity in a human cell line. Toxicol Appl Pharmacol. 2009;234(2): 222-235.

129. Griffiths SM, Singh N, Jenkins GJ, et al. Dextran coated ultrafine superparamagnetic iron oxide nanoparticles: compatibility with common fluorometric and colorimetric dyes. Anal Chem. 2011;83(10):3778-3785.

130. Kettiger H, Schipanski A, Wick P, Huwyler J. Engineered nanomaterial uptake and tissue distribution: from cell to organism. Int J Nanomedicine. 2013;8:3255-3269.

131. Raspopov RV, Gmoshinskii IV, Popov KI, Krasnoiarova OV, Khotimchenko SA. [Methods of nanoparticles control in food and biological objects. Report 1 . Use of microscopic and chromatography investigation methods]. Vopr Pitan. 2012;81(2):4-11. [Russian].

132. Arora S, Rajwade JM, Paknikar KM. Nanotoxicology and in vitro studies: the need of the hour. Toxicol Appl Pharmacol. 2012;258(2): 151-165.

133. Clift MJ, Gehr P, Rothen-Rutishauser B. Nanotoxicology: a perspective and discussion of whether or not in vitro testing is a valid alternative. Arch Toxicol. 2011;85(7):723-731.

134. Dhawan A, Sharma V. Toxicity assessment of nanomaterials: methods and challenges. Anal Bioanal Chem. 2010;398(2):589-605.

135. Kroll A, Dierker C, Rommel C, et al. Cytotoxicity screening of 23 engineered nanomaterials using a test matrix of ten cell lines and three different assays. Part Fibre Toxicol. 2011;8:9.

136. Hanley C, Thurber A, Hanna C, Punnoose A, Zhang JH, Wingett DG. The Influences of cell type and $\mathrm{ZnO}$ nanoparticle Size on immune cell cytotoxicity and cytokine induction. Nanoscale Res Lett. 2009;4(12): 1409-1420. 
137. Donaldson K, Borm PJ, Castranova V, Gulumian M. The limits of testing particle-mediated oxidative stress in vitro in predicting diverse pathologies; relevance for testing of nanoparticles. Part Fibre Toxicol. 2009;6:13.

138. Kim JS, Peters TM, O'Shaughnessy PT, Adamcakova-Dodd A, Thorne PS. Validation of an in vitro exposure system for toxicity assessment of air-delivered nanomaterials. Toxicol In Vitro. 2013;27(1):164-173.

139. Costantino L, Boraschi D. Is there a clinical future for polymeric nanoparticles as brain-targeting drug delivery agents? Drug Discov Today. 2012;17(7-8):367-378.

140. Laurent S, Burtea C, Thirifays C, Hafeli UO, Mahmoudi M. Crucial ignored parameters on nanotoxicology: the importance of toxicity assay modifications and "cell vision". PLoS One. 2012;7(1):306-314.

141. Lesniak A, Campbell A, Monopoli MP, Lynch I, Salvati A, Dawson KA. Serum heat inactivation affects protein corona composition and nanoparticle uptake. Biomaterials. 2010;31(36):9511-9518.

142. Mahmoudi M, Monopoli MP, Rezaei M, et al. The protein corona mediates the impact of nanomaterials and slows amyloid beta fibrillation. Chembiochem. 2013;14(5):568-572.

143. Mirshafiee V, Mahmoudi M, Lou KY, Cheng JJ, Kraft ML. Protein corona significantly reduces active targeting yield. Chem Commun. 2013;49(25):2557-2559.

144. Salvati A, Pitek AS, Monopoli MP, et al. Transferrin-functionalized nanoparticles lose their targeting capabilities when a biomolecule corona adsorbs on the surface. Nat Nanotechnol. 2013;8(2):137-143.

145. Takhar $P, M a h a n t S$. In vitro methods for nanotoxicity assessment: advantages and applications. Arch Appl Sci Res. 2011;3(2):389-403.
146. Block ML, Elder A, Auten RL, et al. The outdoor air pollution and brain health workshop. Neurotoxicology. 2012;33(5):972-984.

147. Rodier PM. Environmental causes of central nervous system maldevelopment. Pediatrics. 2004;113(4):1076-1083.

148. Sparkman NL, Johnson RW. Neuroinflammation associated with aging sensitizes the brain to the effects of infection or stress. Neuroimmunomodulat. 2008;15(4-6):323-330.

149. von Bernhardi R, Tichauer JE, Eugenin J. Aging-dependent changes of microglial cells and their relevance for neurodegenerative disorders. J Neurochem. 2010;112(5):1099-1114.

150. Carvey PM, Punati A, Newman MB. Progressive dopamine neuron loss in Parkinson's disease: the multiple hit hypothesis. Cell Transplant. 2006;15(3):239-250.

151. Qin LY, Wu XF, Block ML, et al. Systemic LPS causes chronic neuroinflammation and progressive neurodegeneration. Glia. 2007;55(5):453-462.

152. Giordano G, Tait L, Furlong CE, Cole TB, Kavanagh TJ, Costa LG. Gender differences in brain susceptibility to oxidative stress are mediated by levels of paraoxonase-2 expression. Free Radical Bio Med. 2013;58:98-108.

153. Costa LG, de Laat R, Dao K, Pellacani C, Cole TB, Furlong CE Paraoxonase-2 (PON2) in brain and its potential role in neuroprotection. Neurotoxicology. 2014;43:3-9.

154. Segal MB. The choroid plexuses and the barriers between the blood and the cerebrospinal fluid. Cell Mol Neurobiol. 2000;20(2):183-196.
International Journal of Nanomedicine

\section{Publish your work in this journal}

The International Journal of Nanomedicine is an international, peerreviewed journal focusing on the application of nanotechnology in diagnostics, therapeutics, and drug delivery systems throughout the biomedical field. This journal is indexed on PubMed Central, MedLine, CAS, SciSearch $®$, Current Contents $\AA /$ Clinical Medicine,

\section{Dovepress}

Journal Citation Reports/Science Edition, EMBase, Scopus and the Elsevier Bibliographic databases. The manuscript management system is completely online and includes a very quick and fair peer-review system, which is all easy to use. Visit http://www.dovepress.com/ testimonials.php to read real quotes from published authors. 